\title{
RAINFALL THRESHOLD FOR INITIATING EFFECTIVE STRESS DECREASE AND FAILURE IN WEATHERED TEPHRA SLOPES
}

\author{
Max Oke Kluger ${ }^{1 *}$, M. Ehsan Jorat ${ }^{2}$, Vicki G. Moon ${ }^{3}$, Stefan Kreiter ${ }^{4}$, Willem de \\ Lange $^{5}$, Tobias Mörz ${ }^{6}$, Thomas Robertson ${ }^{7}$, David J. Lowe ${ }^{8}$
}

${ }^{1}$ MARUM - Research Faculty, University of Bremen, Leobener Straße 8, 28359 Bremen, Germany, Orcid:0000-0001-9130-8948

${ }^{2}$ School of Applied Sciences, Abertay University, Dundee, DD11HG, United Kingdom, Orcid: 0000-0001-6972-5921

${ }^{3}$ School of Science, University of Waikato, Hamilton, New Zealand, Orcid:0000-0001-73788490

${ }^{4}$ MARUM - Research Faculty, University of Bremen, Leobener Straße 8, 28359 Bremen, Germany, Orcid:0000-0002-1110-7765

${ }^{5}$ School of Science, University of Waikato, Hamilton, New Zealand, Orcid: 0000-0002-64670308

${ }^{6}$ MARUM - Research Faculty, University of Bremen, Leobener Straße 8, 28359 Bremen, Germany, Orcid:0000-0002-6865-7864

${ }^{7}$ School of Science, University of Waikato, Hamilton, New Zealand

${ }^{8}$ School of Science, University of Waikato, Hamilton, New Zealand, Orcid: 0000-0002-25476019

*Corresponding author, Email: mkluger@marum.de

\section{Citation:}

Kluger, M.O., Jorat, M.E., Moon, V.G., Kreiter, S., de Lange, W.P., Mörz, T., Robertson, T., Lowe, D.J. 2020. Rainfall threshold for initiating effective stress decrease and failure in weathered tephra slopes. Landslides DOI: 10.1007/s10346-019-01289-2 (online from 19 October 2019) 


\section{Abstract}

2 Rainfall is one of the most important triggers of slope failure. Weathered pyroclastic (tephra)

3 deposits are especially vulnerable to slope failure because they commonly form slopes of high 4 porosity and high clay content. Empirically-derived thresholds for the triggering of landslides 5 are commonly based on rainfall conditions and have been widely applied in volcanic soils. 6 However, so far only few researchers utilized pore water pressure in the slope as additional 7 variable for the threshold calibration. Here we derived a new rainfall threshold for initiating the 8 decrease in effective stress in the slope by analyzing a long-term record of rainfall and piezom9 eter data from a slide-prone coastal area in northern New Zealand that consists of clayey, hal10 loysitic tephra deposits. The level of effective stress decrease increases with rainfall intensity 11 and duration. We observed highest effective stress decrease of up to $36 \%$ during rainfall events 12 that triggered landslides in our study area. The effective stress threshold exhibits a satisfactory 13 predictive capability. The probability of correctly predicting a decrease in effective stress is $1453 \%$. The effective stress threshold contributes towards the implementation of the decrease in 15 effective stress into rainfall thresholds for the occurrence of landslides.

17 Keywords landslides; rainfall threshold; effective stress; weathered tephra; spheroidal hal18 loysite; rainfall-induced slope failure 


\section{INTRODUCTION}

Rainfall-induced landslides occur globally in all types of environments, posing a major natural hazard to people and infrastructure. Coastal environments are especially vulnerable to landslides because they often consist of highly populated terrain with steep slopes (Agostini et al., 2014; Assier-Rzadkieaicz et al., 2000; Longva et al., 2003; Rösner, 2016). The severity of landslides is further controlled by the presence of sensitive soils in the slope. The special role of sensitive soils is their pronounced post-failure softening behavior, which may lead to progressive landslides with long runout distance that are difficult to predict (Demers et al., 2014; Kvalstad et al., 2005; L'Heureux et al., 2014). Tephra deposits, encompassing all pyroclastic materials of any grain size (Lowe, 2011), are highly susceptible to slope failure and have been responsible for catastrophic landslides (Chigira, 2014; Sidle and Ochiai, 2006). Halloysite is a common weathering product of rhyolitic (silica-rich) tephra (Churchman and Lowe, 2012) and has been found to dominate slide surfaces of rainfall-induced landslides in Hong Kong, Japan, New Zealand, Hawaii, and the conterminous United States (Chigira, 2014; Chigira and Yokoyama, 2005; Irfan, 1992, 1998; Kirk et al., 1997; Kluger et al., 2017; Parry et al., 2000, 2001; Shaller et al., 2016; Taskey, 1977; Wen and Aydin, 2003; Yamao et al., 2016). Halloysite is known to form low-permeability soils with high sensitivity (Kluger et al., 2017; Moon et al., 2015b; Smalley et al., 1980). A Review by Chigira (2014), for example, highlighted the importance of better understanding the trigger mechanisms and landslides dimensions in halloysitic soils.

Reduction of effective stress due to rainfall-induced excess pore water pressure is a significant trigger of landslides (Cruden and Varnes, 1996). Rainfall thresholds are widely used to forecast the likely occurrence of landsliding by defining the minimum rainfall necessary to trigger landslides (Segoni et al., 2018a). Caine (1980) developed a first global rainfall threshold, which links rainfall intensity and duration to the occurrence of landslides. Since then, a large variety of rainfall thresholds have been derived at different scales (global, regional, local), by using different rainfall parameters (rainfall intensity, duration, antecedent precipitation), and for various types of landslides (Guzzetti et al., 2007, 2008; Segoni et al., 2018a). In their recent review, Segoni et al. (2018a) summarized that most rainfall thresholds were derived for shallow landslides and debris flows, whereas only few rainfall thresholds for deep-seated landslides, rockslides, and earthflows had been studied. Furthermore, Segoni et al. (2018a) recognized that most studies solely rely on rainfall data when calibrating rainfall thresholds. They found only two case studies - Baum and Godt (2010) and Napolitano et al. (2016) - in which pore water pressure data provided additional insight into the trigger mechanism of landslides. Understanding changes in pore water pressure due to rainfall is needed to calculate changes in effective stress in the soil slope (Duncan et al., 2014) and its evaluation would therefore offer a new beneficial perspective in the determination of rainfall thresholds (Segoni et al., 2018a).

\subsection{Suitability of study area}


Our study area is the Omokoroa Peninsula ('Omokoroa' hereafter), located in the central part of Tauranga Harbour, New Zealand's largest barrier-enclosed estuarine lagoon (Fig. 1A-B). Omokoroa's geology consists mainly of a thick succession of Quaternary-aged rhyolitic tephra-fall deposits derived largely from eruptions in the Taupo Volcanic Zone, together with intercalated paleosols, underlain by ignimbrite (Briggs et al., 2005). One specific composite unit within the siliceous tephra succession, the Pahoia Tephra sequence ('Pahoia Tephras' hereafter), has been highly weathered to form clay-rich deposits dominated by halloysite and has very high sensitivities (Kluger et al., 2017; Smalley et al., 1980). These highly sensitive Pahoia Tephras were involved in the deep-seated Bramley Drive landslide, located on the northwest coast of Omokoroa (Kluger et al., 2017; Moon et al., 2015b). The main failure occurred in 1979 after prolonged heavy rainfall and was reactivated by smaller retrogressive failures in 2011, and 2012. The Pahoia Tephras, acting as an aquiclude as well as sliding material, were transported over long runout distances into Tauranga Harbour. During two rainfall events associated with cyclones Debbie and Cook in 2017, 27 new landslides occurred along the coast of Omokoroa causing damage to numerous houses and properties (Tab. 1C-E). This study area is therefore ideal for investigating trigger mechanisms and landslide dimensions of rainfall-induced landslides in sensitive halloysitic tephras, and demonstrably important also for informing landslide hazard analysis and potential mitigation (Basher, 2013; Crozier, 2005).

\subsection{Outline of our approach}

In this study, we used field observations including mapping of landslides, and a combination of bathymetry and seismic data, to identify the failure dimensions and geological preconditioning factors of the landslides at Omokoroa. We then compare these features with those of landslides in various material types and environments worldwide. By analyzing 4.5 years of rainfall and pore water pressure data recorded at the Bramley Drive landslide since 2014, we calibrated and validated empirical rainfall thresholds for the occurrence of landslides and for the initiation of effective stress decrease in the slope.

\section{GEOLOGICAL SETTING}

The Tauranga basin extends along the Bay of Plenty coastline on the northeastern part of New Zealand's North Island (Briggs et al., 1996) (Fig. 1B). The Waiteariki Ignimbrite, deposited c. 2.09 Ma (Briggs et al., 2005), forms the local basement. Its eruption initiated a period of rapid subsidence (Houghton and Cuthbertson, 1989). The ensuing basin was infilled in part by volcanogenic sediments, ignimbrites, and silica-rich tephra-fall deposits originating from eruptions in the Coromandel Volcanic Zone and the Taupo Volcanic Zone. The post-glacial marine transgression after the Last Glacial Maximum (attaining near-modern sea level c. 7,500 years ago) formed a large barrier-enclosed mesotidal estuarine lagoon, the Tauranga Harbour (Briggs et al., 1996). The lagoon is blocked from the sea by two tombolos at Bowentown and Mt Maunganui, and the Pleistocene and Holocene barrier island of Matakana Island (Shepherd et al., 2000). Most of the lagoon comprises extensive estuaries and mudflats. A number of 
terraces extend into Tauranga Harbour as northeast- to north-northeast-trending peninsulas, which commonly have near-level surfaces 20 to $40 \mathrm{~m}$ above sea level and steep slopes or cliffs on their coasts that are prone to landsliding (Briggs et al., 1996; Chappell, 1975).

One of these peninsulas is that at Omokoroa (Fig. 1A), which has experienced numerous coastal landslides (Fig. 1C-E). Omokoroa stratigraphically comprises a 40-m-thick succession of mainly Quaternary rhyolitic tephras (Fig. 2A): the Pahoia Tephra sequence includes (from base to top) lignite, paleosol P1, nonwelded pumiceous deposits of the Te Puna Ignimbrite (c. $0.93 \mathrm{Ma}$ ), and a series of weathered clay-rich halloysitic tephra beds, which are divided into lower and upper Pahoia Tephras based one distinct paleosol (P2). All of these deposits and intercalated paleosols are overlain by successions of younger, strongly-weathered tephras called Hamilton Ashes (c. 0.35 to c. $0.05 \mathrm{Ma}$ ) and late Quaternary tephras $(\leq$ c. $0.05 \mathrm{Ma})$. Apart from the near-surface late Quaternary tephras (which are mainly allophanic), the tephras have been weathered to halloysites with different morphologies, ranging from mainly tubular in the Hamilton Ashes and Upper Pahoia Tephras, to mainly spheroids in the lower Pahoia Tephras, and to mainly polyhedrons and books in the Te Puna Ignimbrite (Cunningham et al., 2016; Kluger et al., 2017). The lower Pahoia Tephras include the highly sensitive halloysitic layer that was involved in the failure of the 1979 Bramley Drive landslide (Fig. 2B-C). Kluger et al. (2017) reported a new mushroom cap-shaped variety of the spheroidal halloysite morphology (Fig. 2D), which, through its surface-charge characteristics, causes the layer to be highly sensitive and thus contributes to the landslide susceptibility at Omokoroa. The highly sensitive halloysitic layer is porous (Smalley et al., 1980), but has also low permeability (Moon et al., 2015b), affecting the hydrogeology of the tephra successions at Omokoroa. Based on piezometer recordings at the Bramley Drive landslide, an aquiclude located in the lower Pahoia Tephras prohibits downward directed drainage of rainwater, whereas an overlying aquifer is directly connected to the surface and allows rain induced effective stress fluctuations in the slope (Moon et al., 2015a).

\section{MATERIALS AND METHODS}

\subsection{Landslide characterization}

122 The landslides that occurred at Omokoroa's coast since the 1979 Bramley Drive landslide were characterized according to material composition, type, volume, and travel angle. We performed a detailed mapping survey of landslide after the 2017 cyclone season in April 2017. The mapping of landslides included the following steps. The lithological compositions of the slides were identified by descriptions of samples taken from the landslide scarp and slide debris, or alternatively through observation of exposed scarp faces and correlations to the known regional stratigraphy at Omokoroa. The landslides were classified according to Cruden and Varnes (1996), being either deep-seated (with rotational slip surface), shallow, or composite earth slides. The composite earth slides always resulted from both deep-seated and shallow failures and are hereafter attributed either to the deep-seated or shallow earth slides on the 
basis of the dominant mode of failure. The decision about which mode of failure dominated the landslide was made by the authors' expert knowledge. We calculated volumes of deep-seated landslides $V_{d s}$ by assuming the slip surfaces followed the shape of half an ellipsoid with semiaxes $D_{s}, W_{S} / 2$, and $L_{s}$ (Eq. 1 , Cruden and Varnes, 1996).

$V_{d s}=\frac{1}{6} \pi D_{s} \cdot W_{s} \cdot L_{s}$

where $L_{S}$ is the distance from toe of slip surface to crown of the main scarp. $W_{S}$ is the maximum width between flanks of the landslide perpendicular to $L_{S}$. $D_{S}$ is the maximum depth of the slip surface below original ground surface, measured perpendicular to the plane containing $W_{S}$ and $L_{S}$. The orientation of the original ground surface was derived from a 1-m-resolution LIDAR digital elevation model of Omokoroa, which was recorded before the landslides in 2015. It is accepted practice to estimate volumes of shallow landslides $V_{S}$ (Eq. 2) from landslide area $A_{L}$ (Eq. 3) and two empirically derived parameters, namely the scaling exponent $c$ and intercept $a$ (Guzzetti et al., 2009; Larsen et al., 2010; Malamud et al., 2004).

$V_{s}=a A_{L}^{c}$

$A_{L}=W_{S} \cdot L_{S}$

In our study, we used a scaling exponent of $c=1.332$ and an intercept of $\log (a)=-0.836$ to estimate volumes of shallow landslides. These values are derived from an international database of soil landslides (Larsen et al., 2010). The travel angle $\beta$ of landslides is calculated following Cruden and Varnes (1996) using Eqs. 4 and 5.

$$
\tan (\beta)=H / L
$$

$\beta=\tan ^{-1}\left(\frac{H}{L}\right)$

where $H / L$ is the height-to-length ratio (Cruden and Varnes, 1996), which is calculated from the vertical $H$ and horizontal distances $L$ between crown and tip of the landslide deposits, respectively. The volume and travel angle of the 1979 Bramley Drive landslide were estimated from Gulliver and Houghton (1980).

We further studied the volumes and travel angles of historical landslides that occurred at Omokoroa by surveying the geological record of the sediments deposited in the subtidal area close to Omokoroa's coast. By using a $200 / 400 \mathrm{kHz}$ shallow water multibeam echosounder (Reson Seabat 7125) onboard vessel Pandora, and a $3.5 \mathrm{kHz}$ seismic system (Knudsen Pinger CHIRP SBP) mounted on vessel Tai 
Rangahau, we mapped the seafloor morphology and sedimentary subsurface structures of potential remnant landslide deposits. The bathymetric and seismic data cover an elongated northeast-trending area c. $1,300 \mathrm{~m}$ long and c. $250 \mathrm{~m}$ wide (Fig. 1A). The bathymetric data have a grid resolution of $1 \mathrm{~m}$ by $1 \mathrm{~m}$ and the seismic data form a grid of approximately parallel profiles with c. $50 \mathrm{~m}$ spacing.

\subsection{Evaluation of rainfall and pore water pressure}

We consider our study area at Omokoroa to be of local scale, with maximal length of 1,800 m, maximal width of $300 \mathrm{~m}$, and an area of c. $0.5 \mathrm{~km}^{2}$. Rainfall that occurred from January 2014 to June 2018 was therefore recorded by a single tipping bucket rain gauge (Ogawa Seiki Co.) located close to the Bramley Drive landslide (Fig. 1A) (Moon et al., 2015a). According to Segoni et al. (2018a), a rain gauge density of 200 per $100 \mathrm{~km}^{2}$, as used in our study, is within the middle range considered in recent studies about rainfall thresholds. The maximal distance between the rain gauge and landslides was c. $1000 \mathrm{~m}$. The rain gauge at the Bramley Drive landslide exhibited time periods with data gaps (Fig. 3B). We therefore supplemented the missing record with rainfall data collected from the nearest available rain gauge at Goodall Road, Whakamarama, being located c. $6.5 \mathrm{~km} \mathrm{SW}$ of Omokoroa (Fig. 1B). Because rainfall within Tauranga Harbour has been observed to be variable (Quayle, 1984), we confirmed the accordance between both rainfall regimes by statistical correlation (Fig. 3C-D). For this purpose, we identified rainfall events that were recorded by both rain gauges and found that cumulated rainfall and rainfall duration at the Bramley Drive landslide are both well represented by the rain gauge at Goodall Road, Whakamarama. The sampling rates for the rainfall gauges were every 10 minutes at the Bramley Drive landslide and every 60 minutes at Goodall Road, Whakamarama. Because of that difference, we resampled the rainfall data of both stations to hourly rainfall.

We analyzed the rainfall and piezometer data to relate rainfall parameters (cumulated rainfall, rainfall intensity, and duration) of individual rainfall events to pore water pressure increase and to the triggering of landslides. The extraction of rainfall parameters from the rainfall data and the separation of individual rainfall events was based on defining a standard time period without rainfall. The duration of dry periods commonly chosen for separating individual rainfall events varies from six hours (Tiranti and Rabuffetti, 2010) to four days (Brunetti et al., 2010). In our study, the pore water pressure from rainfall dissipated 
within a few hours after the rainfall stopped and never exceeded six hours (Fig. 3E). Therefore, we defined an individual rainfall event as continuous rainfall being separated from the next rainfall event by a dry period of at least six hours (following the suggestions made by Tiranti and Rabuffetti, 2010). For each rainfall event, we calculated the cumulated rainfall, duration, and rainfall intensity. We classified the rainfall events that caused an increase in pore water pressure in at least one of the piezometers as 'large rainfall events', and those with no impact on the pore water pressure as 'small rainfall events.' Destabilization of the soil slope because of large rainfall events was assessed by considering the decrease in effective stress due to pore water pressure. The effective stress $\sigma^{\prime}$ was calculated using Eq. 6 .

$\sigma^{\prime}=\sigma-u$

where $\sigma$ is the total overburden stress, which we estimated from long-spaced gamma density logging in the slope of the Bramley Drive landslide (Kluger et al., 2018), and $u$ is the pore water pressure measured by the piezometers.

All 27 landslides since January 2014 were observed shortly after two large rainfall events during cyclones Debbie and Cook in 2017. The timings of these landslides were solely based on eye witness reports of residents living close to the coast of Omokoroa, yielding a temporal resolution of landslide occurrence of about one day. The attribution of rainfall events to the triggering of landslides was therefore performed manually, without any measurement of soil displacement during landslides. Because of the low number of rainfall events $(N=2)$ that triggered landslides, we did not derive own rainfall thresholds for the occurrence of landslides, but compared the two large rainfall events during cyclones Debbie and Cook that triggered landslides at Omokoroa to the global rainfall intensity-duration threshold suggested by Caine (1980), which was later updated by Sidle and Ochiai (2006) (Eq. 7).

$I=\alpha D^{-\gamma}$

where $I$ is the rainfall intensity $(\mathrm{mm} / \mathrm{h}), D$ is the duration of rainfall $(\mathrm{h})$, and $\alpha=13.58$ and $\gamma=0.38$ 232 are the intercept and slope of the power law function, respectively. Additionally, we adopted the Frequentist method to statistically analyze rainfall events that caused an effective stress decrease (i.e. large rainfall events) and calibrated a rainfall intensity-duration threshold for the beginning of effective stress decrease. The Frequentist method was first described by Brunetti et al. (2010) and has since been applied in several study areas in Italy (Peruccacci et al., 2012; Segoni et al., 2018a). Following Brunetti et al. (2010), we applied frequency analysis on the large rainfall events and calibrated a rainfall threshold (Eq. 7) for the beginning of effective stress decrease at the $5 \%$ confidence interval. Assuming the catalogue of large rainfall events sufficiently represents the rainfall conditions at Omokoroa, we can state 
240 that the probability of effective stress decrease by rainfall below this threshold is less than 5\% (Brunetti

et al., 2010).

We validated the predictive capability of the global rainfall threshold of Sidle and Ochiai (2006) and our new effective stress threshold by compiling contingency matrices (one for each threshold) that classify rainfall events as either true positives $(T P)$, true negatives $(T N)$, false positives $(F P)$, or false negatives $(F N)$ (Tab. 2). The validation was performed using the entire data set of rainfall events between January 2014 and June 2018. The contingency matrices were used to calculate different skill scores (sensitivity, specificity, positive prediction power, negative prediction power), all of which are common statistical parameters to evaluate predictive capability (Martelloni et al., 2012; Rosi et al., 2015; Segoni et al., 2018a).

\section{COASTAL LANDSLIDES IN HALLOYSITIC TEPHRA DEPOSITS}

\subsection{Preconditioning factors}

Many landslides occurred along the northwest coast of Omokoroa as a consequence of two large rainfall events during cyclones Debbie and Cook in 2017. We counted a total of 27 coastal landslides and overlaid the topography in Fig. 1A with our mapping results of main scarps and dimensions of landslide deposits. The landslides have an average spacing distance of $80 \mathrm{~m}$ between one another and affected the highly populated coastal residential area of Omokoroa (Fig. 1C-E). The majority of landslides resulted from shallow slope-parallel failures within the upper unwelded pumiceous deposits of the Te Puna Ignimbrite and overlying halloysitic tephra deposits of the Pahoia Tephras (c.f. Fig. 1C, Table 1). Shallow landslides occur occasionally along the entire coastline and become dominant at the eastern coast along Myrtle Drive and Crapp Reserve (Fig. 1A).

We counted ten landslides that were deep-seated. One of these, the McDonnell Street landslide (L-9), followed a failure and sliding mechanism similar to that of the 1979 Bramley Drive landslide (L-11). Both landslides, depicted in Figs. 1D-E, resulted from an initial rotational failure that reached into the highly sensitive lower Pahoia Tephras. The landslide masses then eroded the upper parts of the Te Puna 268 Ignimbrite until they reached sea level and formed flow slides into the lagoon of Tauranga Harbour (Gulliver and Houghton, 1980). The benches of the initial rotational failures are highlighted by white dashed lines in Figs. 1D-E. The other deep-seated landslides resulted from rotational failures, which were sometimes associated with minor shallow slides.

273 Preconditioning factors for landslides have been widely discussed in the literature (Cruden and Varnes, 1996; Duncan et al., 2014; Varnes, 1978). We consider that the most important preconditioning factors for the coastal landslides at Omokoroa lie in a combination of toe erosion, low permeability, being in the order of $5 \cdot 10^{-10} \mathrm{~m} / \mathrm{s}$, and high sensitivity of the halloysitic tephra layers within the lower Pahoia 
Tephras (Kluger et al., 2018; Kluger et al., 2017; Moon et al., 2015b). Low-permeability clay layers interbedded in soil slopes can occur in all types of deposits and environments worldwide and these situations probably represent the most intensely studied preconditioning factor for pore water pressureinduced landslides (Zaruba and Mencl, 2014). Regardless of the clay layers' mineralogy, their lowpermeability reduced water infiltration into the slope, therefore increased pore water pressure in the overlying aquifer. Following the effective stress principle (Eq. 3) and the Mohr-Coulomb failure criterion, an increase in pore water pressure causes a reduction in effective stress, and consequently a reduction in shear strength (Labuz and Zang, 2012). Where pore water pressure reduces the shear strength of the slope material to the critical level, landslides are triggered.

Sensitivity is the ratio of maximum shear strength to post-failure residual shear strength, where a value of more than 30 is defined as highly sensitive (Norsk Geoteknisk Forening, 1974; Skempton and Northey, 1952). Kluger et al. (2017) studied the relationship between halloysite clay morphology and sensitivity in intact tephras from the Bramley Drive landslide and measured the highest sensitivities of $S=55$ in mushroom cap-shaped spheroidal halloysite, whereas sensitivity development was lower $(S \leq$ 10) in tubular halloysite. The mushroom cap-shaped spheroidal halloysite is most abundant in the lower Pahoia Tephras, which have been involved in the failure of the 1979 Bramley Drive landslide (Figs. 1E and 2). Our observations of the compositions of the slide material show that $30 \%$ of the deep-seated landslides initially failed within the lower Pahoia Tephras (Table 1). Furthermore, a two-third of shallow-translational landslides also involved failure within the Pahoia Tephras. These observations highlight the special role of spheroidal halloysite in landslides at Omokoroa. Similar observations have also been reported in Japan, where 'ball-shaped' halloysite was associated with slip surfaces in weathered tephras (Tanaka, 1992).

Spheroidal halloysite is commonly formed by rapid precipitation from silicon-rich and aluminum-bearing solutions derived from the dissolution of volcanic glass shards and primary mineral grains (Cravero and Churchman, 2016; Joussein et al., 2005). Researchers have reported the occurrence of spheroidal halloysites in cold to tropical regions around the world within various volcanogenic host materials of rhyolitic, andesitic, and basaltic composition (Adamo et al., 2001; Askenasy et al., 1973; Birrell et al., 1955; De Oliveira et al., 2007; Jeong and Kim, 1996; Kirkman, 1977; Loughnan and Roberts, 1981; Parham, 1970; Quantin and Rambaud, 1987; Romero et al., 1992; Saigusa et al., 1978; Sieffermann and Millot, 1969; Singer et al., 2004; Wada and Kakuto, 1985). Furthermore, neoformation of spheroidal halloysite was also observed in tephra layers offshore from Sumatra and Peru (Imbert and Desprairies, 1987; Pouclet et al., 1990). This global occurrence shows the importance of better understanding the role of spheroidal halloysite in sensitivity development and its role in preconditioning large landslides with a progressive failure mechanism. 


\subsection{Landslide dimensions}

1315

We evaluated the dimensions of the landslides that have occurred along the coast of Omokoroa since 1979 (Fig. 4). The majority of landslides are of relatively small volumes, ranging between $\sim 100$ and $4,500 \mathrm{~m}^{3}$, and steep travel angles between $17^{\circ}$ and $60^{\circ}$ (Table 1). Notable exceptions are the McDonnell Street landslide (L-9) and the 1979 Bramley Drive landslide (L-11), having volumes of c. 11,000 and $60,000 \mathrm{~m}^{3}$ and travel angles of $15^{\circ}$ and $9^{\circ}$, respectively. On a log-log scale, the travel angles of landslides observed in our study linearly decrease with landslide volume, indicating and exponential increase in runout distance with landslide volume. We observed that deep-seated landslides generally exhibited higher volumes and lower travel angles than shallow landslides, but that both landslide types follow the same volume-to-travel angle relationship (c.f. power law fit (a) in Fig. 4).

The coastal erosion of the peninsulas within Tauranga Harbour, ensuing after the post-glacial transgression, was likely to be accompanied by different forms of mass wasting, such as landslides. Therefore, we posited that studying the record of nearshore sediments would enable us to recognize dimensions of landslides that occurred along Omokoroa's coast in the past. The seismic and bathymetry data cover the subtidal nearshore area off northwest Omokoroa and provide a three-dimensional view of four sedimentary units (Units 1 to 4 ) identified within the upper $15 \mathrm{~m}$ below the sea surface (Figs. 1A and 5). The basal Unit 1 is characterized by high impedance with little internal structure. The upper boundary of Unit 1 is defined by an undulating reflector having several peaks that are commonly separated by terraced troughs. The overlying Unit $2 \mathrm{a}$ is internally characterized by numerous reflectors of varying orientation. We identified a channel-like structure within this unit (Unit $2 b$ ) with cross-bedded reflectors. The overlying Unit 3a truncates the top reflector and some of the internal inclined reflectors of the channel-like Unit $2 b$. Unit $3 b$ truncates Units $2 a, 2 b$, and $3 a$. Both truncating units are of low impedance. Unit $3 \mathrm{a}$ exhibits some poorly defined chaotic internal reflectors with preferred inclination towards the northwest, whereas Unit $3 \mathrm{~b}$ is horizontally oriented without any internal reflectors. Units 2 and 3 are overlain by a thin slope-parallel unit (Unit 4), which is recognizable in the shallow southeast area of the near-shore waters.

We interpret the basal Unit 1 to be the local basement consisting of the Waiteariki Ignimbrite. Unit 2 represents estuarine and fluvial volcanogenic sediments of mainly volcanogenic origin from the eroded Waiteariki Ignimbrite and newer ignimbrites and multiple tephra-fall deposits, such as the Te Puna Ignimbrite and Pahoia Tephras, respectively. The younger Units $3 \mathrm{a}$ and $3 \mathrm{~b}$ are erosive by nature and exhibit either chaotic internal reflectors or no reflector at all. We therefore interpret them to be deposits of two major pre-historic landslide events that occurred at Omokoroa at the end of the post-glacial transgression when the coastline of Omokoroa was located close to that of the present day. 
Given the close proximity to Omokoroa, it is possible that the pre-historic landslide deposits are composed of sensitive halloysitic tephra materials originating from the lower Pahoia Tephras. This interpretation is supported by the findings of Jorat et al. (2017), who identified Pahoia Tephra landslide deposits in the eastern part of Tauranga Harbour. The slope-parallel layer (Unit 4) only occurs slightly below the intertidal zone and is therefore likely composed of sediments influenced by tides or storm waves, or both. We suggest that the second pre-historic landslide deposits (Unit 3b) in the subtidal area off Omokoroa followed a similar sliding mechanism to that of the two deep-seated failures with associated flow slides (L-9 and L-11). The first pre-historic landslide deposits (Unit 3a) was only observed in few seismic profiles and is therefore not further considered in this stud. We interpolated the extent of the second pre-historic landslide deposits within the seismic profiles and superimposed the associated thickness and maximum extent on Fig. 1A. The interpolated thickness of the second pre-historic landslide averages between 0.5 and $1.5 \mathrm{~m}$. Such a thickness is limited to a small area of the assumed landslide area and therefore provides only a rough estimate of the original landslide thickness. Assuming some major tidal erosion of the landslide to have taken place after deposition, we consider a constant layer thickness of 1 $\mathrm{m}$ to be the lower limit bounding the original landslide. The area enclosed by the line of maximum extent and the present-day coastline of Omokoroa is c. $185,000 \mathrm{~m}^{2}$ and, together with an assumed cliff height of $H=35 \mathrm{~m}$ and a maximal runout distance of $L=360 \mathrm{~m}$, results in a landslide volume of $185,000 \mathrm{~m}^{3}$ and a travel angle of $\beta=5.5^{\circ}$.

The volume-to-travel angle relationship of the landslides at Omokoroa are similar to those of other landslides in halloysitic soils from Japan and Hong Kong (Chigira et al., 2013; Irfan, 1992; Kirk et al., 1997; Wang et al., 2014) (Fig. 4), highlighting the applicability of our findings to locations beyond New Zealand. We further compared dimensions of landslides in halloysitic tephra deposits with those in other environments worldwide. When considering landslides with similar volume (e.g., $V=10^{6} \mathrm{~m}^{3}$ ), subaerial landslides commonly exhibit higher travel angles, whereas submarine landslides and quick clay landslides have smaller travel angles than landslides in halloysitic soil (Edgers and Karlsrud, 1982; Hampton et al., 1996; Hsu, 1975; L’Heureux et al., 2012; Nicoletti and Sorriso-Valvo, 1991; Scheidegger, 1973). The comparison with other environments illustrates that landslides in halloysitic soil exhibit travel angles between those of subaerial and submarine and quick clay landslides. A likely explanation for this observation is that weathered tephra deposits along the coast of Omokoroa exhibit high sensitivities, however not being considered as quick clays (Kluger et al., 2017; Torrance, 1983, 1992). Therefore, the travel angles of landslides at Omokoroa are between landslides in quick clays and (non-sensitive) terrestrial soils.

\section{RAINFALL THRESHOLD FOR HALLOYSITIC TEPHRA DEPOSITS}

\subsection{Rainfall-induced pore water pressure increase}


We analyzed the pore water pressure increase due to rainfall in order to better understand the trigger mechanisms of rainfall-induced landsliding in halloysitic tephras. The low-permeability tephras (including the highly sensitive layer) in the lower Pahoia Tephras act as a water infiltration barrier, creating an overlying unconfined aquifer and an underlying confined aquifer in the slope at Bramley Drive (Fig. 2C). Based on data from the middle piezometer, the water table in the overlying unconfined aquifer is located at an average depth of around $15 \mathrm{~m}$ and it exhibits small seasonal but no long-term annual variations (Fig. 3A). The pore water pressure in the unconfined aquifer responds to rainfall events in distinctive spikes, which commonly decay towards background levels within minutes to hours (Fig. 3A and E). We link the distinctive spikes to direct stress transfer from rainwater that infiltrates the capillary fringe of the saturated soil slope above the aquifer. Sometimes the distinctive spikes are followed by smaller pore water pressure increase with longer decay time, which may reflect a temporary rainfallinduced change in gradient of the regional hydraulic head. These smaller pore water pressure increases with longer decay time were not further considered in this study. Based on observations of the lower piezometer, the confined aquifer exhibits small overall variations in pore water pressure, which sometimes mimic the seasonal variations and pore water pressure increases with longer decay time observed in the unconfined aquifer (cf. examples 1 and 2 in Fig. 3A). Except for two minor spikes in 2014, we did not observe any pore water pressure increase that resulted from direct rainwater infiltration into the confined aquifer. This lack of direct increase indicates that the confined aquifer exhibits some connection to the regional hydrogeological system, but it is not in direct contact with the unconfined aquifer.

We enumerated 816 rainfall events within the evaluation period of 4.5 years. Of these, we identified 41 large rainfall events, which caused a direct pore water pressure increase in the unconfined aquifer at Bramley Drive (Fig. 3A-B). Some rainfall data of the large rainfall events are taken from the nearest rain gauge at Goodall Road, Whakamarama (cf. light green circles in Fig. 5B).

We observed some of the largest rainfall events with strong pore water pressure increase during the 2017 cyclone season from March to April 2017 (Fig. 3E). The rainfall events cluster in four groups at intervals of one to two weeks and accumulated a total rainfall of more than $800 \mathrm{~mm}$. The pore water pressure increase recorded during the third and fourth group of rainfall events, namely cyclones Debbie and Cook, rank among the highest recorded during the investigation period, and ultimately triggered all 27 landslides that occurred at Omokoroa since 2014. We therefore conclude that rainfall and pore water pressure measured at the Bramley Drive landslide are characteristic for the other locations of landslides that occurred across the entire northwest coast of Omokoroa.

\subsection{Rainfall thresholds}

We analyzed the rainfall events in order to better understand the role of rainfall intensity and duration in the triggering of landslides and the initiation of effective stress decrease. For this purpose, we plotted 
the water tables associated with small rainfall events with respect to the rainfall intensity and duration (grey circles in Fig. 6). We overlaid the small rainfall events with vertical arrows indicating an increase in water table from the background level due to a large rainfall event. In addition to the change in water table due to rainfall, we considered the decrease in effective stress in the lower Pahoia Tephras as an indicator for strength loss in the soil slope (as defined by Eq. 6). Small rainfall events did not induce any pore water pressure in the unconfined aquifer. The pore water pressure measured at the middle piezometer during the small rainfall events therefore forms a satisfactory statistical basis for calculating the background effective stress level within the lower Pahoia Tephras. From long-spaced gamma density logging in the slope of the Bramley Drive landslide (Kluger et al., 2018), and our long-term piezometer record during small rainfall events, we calculated a total overburden stress of $\sigma=337 \mathrm{kPa}$ and a pore water pressure of $u=65 \pm 5 \mathrm{kPa}$, which yielded a background effective stress of $\sigma_{b}^{\prime}=272 \pm 5 \mathrm{kPa}$ at the middle piezometer (Eq. 6) (cf. Fig. 6B).

Large rainfall events temporarily reduce the effective stress in the lower Pahoia Tephras to a different extent depending on rainfall intensity and duration. The effective stress began to decrease when rainfall intensities exceeded $2 \mathrm{~mm} / \mathrm{h}$ or at durations of more than $2.5 \mathrm{~h}$. The largest effective stress decreases occurred only when rainfall intensities exceeded $4 \mathrm{~mm} / \mathrm{h}$ or at durations of more than $4 \mathrm{~h}$. The large rainfall events during cyclones Debbie and Cook, preceding the landsliding at Omokoroa, caused the highest and third-highest effective stress decrease within the studied time period. The rainfall exhibited remarkably long durations of c. $25 \mathrm{~h}$ at moderate intensities of $4 \mathrm{~mm} / \mathrm{h}$. The large June 2018 rainfall event (as highlighted in Fig. 6B), causing the second-highest effective stress decrease, was not associated with any landslide event. In comparison to the rainfall events during cyclones Debbie and Cook, the June 2018 rainfall event exhibits higher rainfall intensity, but a shorter duration of c. $16 \mathrm{~h}$. These observations indicate that in our study area a duration of rainfall above $16 \mathrm{~h}$ represents a critical level for landslide triggering. For moderate rainfall intensities $(I=4 \mathrm{~mm} / \mathrm{h})$, we can further constrain this critical level of rainfall duration to $25 \mathrm{~h}$. This finding is in accordance with that of Wei et al. (2018), who related shallow landslides in Taiwan to rainfall events having durations of more than $24 \mathrm{~h}$.

Rainfall thresholds are widely used to forecast the likely occurrence of landslides (Guzzetti et al., 2007, 2008; Segoni et al., 2018a). We compared our two rainfall events that triggered landslides since January 2014 with the global rainfall intensity-duration threshold developed by Sidle and Ochiai (2006) (Eq. 7) and with a regional rainfall duration threshold of Wei et al. (2018). For this purpose, we displayed the rainfall intensities and durations of all rainfall events that triggered, or did not trigger, landslides together with the two rainfall thresholds by means of logarithmic and linear scales (Fig. 7). The two rainfall events that triggered landslides are well constrained by both rainfall thresholds. 
The influence of rainfall intensity and duration on effective stress decrease was further evaluated by introducing a normalized effective stress decrease $\Delta \sigma_{N}^{\prime}$, which quantifies the decrease in effective stress from that of the background effective stress in response to large rainfall events (Eq. 8).

$\Delta \sigma_{N}^{\prime}=\left(1-\frac{\sigma_{b}^{\prime}-u}{\sigma_{b}^{\prime}}\right) \cdot 100 \%$

465 We consider the normalization of effective stress decrease is less dependent on characteristic features of our study area, such as depth of the slip surface and aquifer, and hence may be more comparable with the results of studies on other soil slopes worldwide. We color-coded the rainfall events into six different classes of normalized effective stress decrease (cf. legend in Fig. 7B) and performed the Frequentist method to calibrate a power law function for the beginning of effective stress decrease, hereafter referred to as effective stress threshold (Eq. 9).

$I=5.19 D^{-0.30}$

The effective stress threshold and the rainfall threshold of Sidle and Ochiai (2006) separate the rainfall events into three regions (indicated by numbers 1 to 3 in Fig. 7A). For each region, we quantified classes of effective stress decrease by means of frequency distribution (Inset in Fig. 7A). The first region represents all rainfall events below the effective stress threshold and mostly consists of small rainfall events (99.9\%). The second region encompasses all rainfall events between the effective stress threshold and the rainfall threshold of Sidle and Ochiai (2006). Around $45 \%$ of the rainfall events showed reductions in effective stress mainly in the lower classes 2 and 3, which correspond to normalized effective stress decreases between 0 and $15 \%$. In the third region, above the threshold of Sidle and Ochiai (2006), most rainfall events (78\%) caused decreases in effective stress. More than one quarter of rainfall events lie in class 6 , accounting for normalized effective stress decreases between 28 and $36 \%$. These rainfall events also include the two large rainfall events (cyclones Debbie and Cook in 2017) that triggered landslides in our study area. The other rainfall events of class 6 exhibit lower rainfall duration, which may be the reason why landslides were not triggered during them (Wei et al., 2018). However, a considerable proportion of rainfall events above the effective stress threshold (regions 2 and 3) did not cause any effective stress decrease. This finding shows that the effective stress threshold is either not always applicable to rainfall events recorded since January 2014 or that other factors, such as antecedent precipitation, soil moisture, or locally varying rainfall, may have additionally affected the increase in pore pressure in the aquifer at Omokoroa (Rahardjo et al., 2005; Segoni et al., 2018a; Segoni et al., 2018b; Yamao et al., 2016).

\section{RAINFALL THRESHOLD PREDICTABILITY}


We validated the capability of the global rainfall threshold by Sidle and Ochiai (2006), and our new effective stress threshold to predict landslides and the initiation of effective stress, respectively. The two contingency matrices, presented in Table 3, classify rainfall events as either true positives (TP), true negatives $(T N)$, false positives $(F P)$, or false negatives $(F N)$. The contingency matrices were used to calculate different skill scores of predictive capabilities (sensitivity, specificity, positive prediction power, negative prediction power).

Both thresholds exhibit sensitivities $(S e)$ and specificities $(S p)$ close to 1 indicating an overall good predictive capability (Rosi et al., 2015). The positive prediction power ( $P P P)$ of the rainfall threshold of is 0.056 , being at the lower end of values reported in the literature. Rosi et al. (2015) summarized the positive prediction power of numerous rainfall thresholds calibrated for landslides occurrences in the Tuscany region, Italy, and reported values of $P P P=0.105 \pm 0.073$. The lowness in positive prediction power observed in our study is likely because of the small number of rainfall events that triggered landslides in our study. Another factor is probably because the rainfall threshold of Sidle and Ochiai (2006) does not consider a cutoff value in rainfall duration of, e.g. $D=24 \mathrm{~h}$, which was used by Wei et al. (2018) and which seems to be an important threshold in our study area (cf. Fig. 7). Finally, the positive prediction power of the rainfall threshold of Sidle and Ochiai (2006) may be further influenced by the extraction of rainfall parameters from the rainfall data and the separation of individual rainfall events, which we based on a dry period of six hours (Tiranti and Rabuffetti, 2010). The positive prediction power of the effective stress threshold is 0.526 , being a satisfactory value compared to the values reported for other rainfall thresholds (Rosi et al., 2015). Hence, the probability of correctly predicting a decrease in effective stress is $53 \%$. The negative prediction power (NPP) of both thresholds is close to 1 , indicating that they are well capable of correctly predicting rainfall events that did not trigger landslides or that did not cause any decrease in effective stress. The high NPP may also be influenced by the relatively small number of rainfall events applied in this study.

For future research we suggest that the investigative time period could be increased as well as the number and spatial distribution of piezometers within the study area. These measures would, on the one hand, provide a larger data base for threshold calibration and validation, and on the other, would prevent local variabilities in the aquifer and moisture conditions of the soil slope from influencing the calibration of the effective stress threshold. Furthermore, it has yet to be tested whether or not the effective stress threshold is also applicable to other soil materials (e.g., sedimentary clays and sands) and environmental constraints (e.g., dry and tropical) that are significantly different from those of our study area. As Segoni et al. (2018a) pointed out in their recent review, implementation of pore water pressure into calibration of the rainfall thresholds would add a beneficial perspective in future landslide prediction studies. We believe that our effective stress threshold contributes towards the implementation of pore water pressure (and decrease in effective stress) into rainfall thresholds for the occurrence of landslides. 


\section{CONCLUSIONS}

We have studied a 40 -m-thick succession of weathered rhyolitic pyroclastic deposits dating to c. 0.9 Ma that are dominated by halloysite at Omokoroa Peninsula, Tauranga Harbour, the site of multiple landslide events. We showed that for moderate rainfall intensities $(I=4 \mathrm{~mm} / \mathrm{h})$ a rainfall duration of $25 \mathrm{~h}$ was a critical threshold for landsliding, and that the ensuing landslide dimensions, are both in keeping with parameters reported for landslides in halloysitic tephra deposits in Hong Kong and Japan. The normalized effective stress principle and effective stress threshold developed in our study thus provide a better understanding of the rainfall trigger mechanism of landslides in halloysitic soil materials worldwide. Because the rainfall intensity-duration threshold of Sidle and Ochiai (2006) was reproduced very well by our analyses, not only for the shallow-translational but also for the deep-rotational landslides in our study area, we conclude that the rainfall threshold may be extended to these types of landslides in the future. We also found that:

- In our study, landslides were only triggered when rainfall events exceeded both the rainfall threshold of Sidle and Ochiai (2006) as well as the rainfall duration threshold of $D=24 \mathrm{~h}$ proposed by Wei et al. (2018).

- A new effective stress threshold was calibrated based on rainfall events that initiated a decrease in effective stress in the slope. The level of effective stress decrease increases with rainfall intensity and duration. We observed highest effective stress decrease of up to $36 \%$ during rainfall events that triggered landslides in our study area.

- The effective stress threshold exhibits a satisfactory predictive capability. The probability of correctly predicting a decrease in effective stress is $53 \%$. False positives and false negatives are low indicating a high capability of the effective stress threshold to correctly predict rainfall events that did not cause any decrease in effective stress.

\section{ACKNOWLEDGMENTS}

This research was funded by the DFG Research Center MARUM of the University of Bremen, Germany, through INTERCOAST and the University of Waikato in Hamilton, New Zealand. We acknowledge the New Zealand Geotechnical Society (NZGS) for funding parts of this project. We thank the Bay of Plenty Regional Council who provided us with the rainfall data from Goodall Road, Whakamarama. We thank Dirk Immenga, Jimmy Van der Pauw, and Wade Roest for conducting the bathymetric and seismic surveys, and Ben Campbell who helped with the field descriptions of the landslides. We gratefully acknowledge Matt Ikari who provided helpful comments on the manuscript. The article is an output of the EXTRAS project "EXTending TephRAS as a global geoscientific research tool stratigraphically, spatially, analytically, and temporally" led by the International Focus Group on Tephrochronology and 
Volcanism (INTAV) of the Stratigraphy and Chronology Commission (SACCOM) of the International

Union for Quaternary Research (INQUA) for 2015-2019.

\section{REFERENCE CITED}

Adamo, P., Violante, P., and Wilson, M., 2001, Tubular and spheroidal halloysite in pyroclastic deposits in the area of the Roccamonfina volcano (Southern Italy): Geoderma, v. 99, no. 3, p. 295-316.

Agostini, A., Tofani, V., Nolesini, T., Gigli, G., Tanteri, L., Rosi, A., Cardellini, S., and Casagli, N., 2014, A new appraisal of the Ancona landslide based on geotechnical investigations and stability modelling: Quarterly journal of engineering geology and hydrogeology, v. 47, no. 1, p. 29-43.

Askenasy, P., Dixon, J., and McKee, T., 1973, Spheroidal halloysite in a Guatemalan soil: Soil Science Society of America Journal, v. 37, no. 5, p. 799-803.

Assier-Rzadkieaicz, S., Heinrich, P., Sabatier, P., Savoye, B., and Bourillet, J., 2000, Numerical modelling of a landslide-generated tsunami: the 1979 Nice event: Pure and Applied Geophysics, v. 157, no. 10, p. 1707-1727.

- Basher, L. R., 2013, Erosion processes and their control in New Zealand: Ecosystem services in New Zealand-conditions and trends, v. 2013, p. 363-374.

Baum, R. L., and Godt, J. W., 2010, Early warning of rainfall-induced shallow landslides and debris flows in the USA: Landslides, v. 7, no. 3, p. 259-272.

Birrell, K., Fieldes, M., and Williamson, K., 1955, Unusual forms of halloysite: American Mineralogist, v. 40, no. 1-2, p. 122-124.

Briggs, R., Hall, G., Harmsworth, G., Hollins, A., Houghton, B., Hughes, G., Morgan, M., and Whitbread-Edwards, A., 1996, Geology of the Tauranga area: Department of Earth Sciences, University of Waikato.

- Briggs, R., Houghton, B., McWilliams, M., and Wilson, C., 2005, 40Ar/39Ar ages of silicic volcanic rocks in the Tauranga- Kaimai area, New Zealand: dating the transition between volcanism in the Coromandel Arc and the Taupo Volcanic Zone: New Zealand Journal of Geology and Geophysics, v. 48, no. 3, p. 459-469.

Brunetti, M., Peruccacci, S., Rossi, M., Luciani, S., Valigi, D., and Guzzetti, F., 2010, Rainfall thresholds for the possible occurrence of landslides in Italy: Natural Hazards and Earth System Sciences, v. 10, no. 3, p. 447-458.

- Caine, N., 1980, The rainfall intensity-duration control of shallow landslides and debris flows: Geografiska annaler: series A, physical geography, v. 62, no. 1-2, p. 23-27.

- Chappell, J., 1975, Upper Quaternary warping and uplift rates in the Bay of Plenty and west coast, North Island, New Zealand: New Zealand journal of geology and geophysics, v. 18, no. 1, p. 129-154.

Chigira, M., 2014, Geological and geomorphological features of deep-seated catastrophic landslides in tectonically active regions of Asia and implications for hazard mapping: Episodes, v. 37, no. 4, p. 284-294.

Chigira, M., Nakasuji, A., Fujiwara, S., and Sakagami, M., 2013, Catastrophic landslides of pyroclastics induced by the 2011 off the Pacific coast of Tohoku Earthquake, EarthquakeInduced Landslides, Springer, p. 139-147.

Chigira, M., and Yokoyama, O., 2005, Weathering profile of non-welded ignimbrite and the water infiltration behavior within it in relation to the generation of shallow landslides: Engineering geology, v. 78, no. 3, p. 187-207.

- Churchman, G. J., and Lowe, D. J., 2012, Alteration, formation, and occurrence of minerals in soils, in Huang, P. M., Li, Y., and Sumner, M. E., eds., Handbook of Soil Sciences. Properties and Processes, 2nd edition USA, CRC Press, p. 20.21-20.72.

- Cravero, F., and Churchman, G. J., 2016, The origin of spheroidal halloysites: a review of the literature: Clay Minerals, v. 51, no. 3, p. 417-427.

- Crozier, M., 2005, Multiple-occurrence regional landslide events in New Zealand: hazard management issues: Landslides, v. 2, no. 4, p. 247-256. 
Cruden, D. M., and Varnes, D. J., 1996, Landslides: investigation and mitigation. Chapter 3Landslide types and processes: Transportation research board special report, no. 247.

Cunningham, M. J., Lowe, D. J., Wyatt, J. B., Moon, V. G., and Jock Churchman, G., 2016, Discovery of halloysite books in altered silicic Quaternary tephras, northern New Zealand: Clay Minerals, v. 51, no. 3, p. 351-372.

- de Lange, W., 1993, Wave Climate for No. 1 Reach, Port of Tauranga, Tauranga Harbour, Report to the Port of Tauranga Ltd: Hamilton, New Zealand.: Department of Earth Sciences, University of Waikato.

De Oliveira, M. T., Furtado, S., Formoso, M. L., Eggleton, R. A., and Dani, N., 2007, Coexistence of halloysite and kaolinite: a study on the genesis of kaolin clays of Campo Alegre Basin, Santa Catarina State, Brazil: Anais da Academia Brasileira de Ciências, v. 79, no. 4, p. 665681.

- Demers, D., Robitaille, D., Locat, P., and Potvin, J., 2014, Inventory of large landslides in sensitive clay in the province of Québec, Canada: preliminary analysis, in L'Heureux, J.-S., Locat, A., Leroueil, S., Demers, D., and Locat, J., eds., Landslides in Sensitive Clays: From Geosciences to Risk Management: Dordrecht, Springer Netherlands, p. 77-89.

Duncan, J. M., Wright, S. G., and Brandon, T. L., 2014, Soil strength and slope stability, John Wiley \& Sons.

Edgers, L., and Karlsrud, K., 1982, Soil flows generated by submarine slides: Case studies and consequences: Nor. Geotech. Inst. Bull, v. 143, p. 1-11.

Gulliver, C., and Houghton, B., 1980, Omokoroa Point Land Stability Investigation: Tonkin \& Taylor.

Guzzetti, F., Ardizzone, F., Cardinali, M., Rossi, M., and Valigi, D., 2009, Landslide volumes and landslide mobilization rates in Umbria, central Italy: Earth and Planetary Science Letters, v. 279, no. 3-4, p. 222-229.

Guzzetti, F., Peruccacci, S., Rossi, M., and Stark, C. P., 2007, Rainfall thresholds for the initiation of landslides in central and southern Europe: Meteorology and atmospheric physics, v. 98, no. 3-4, p. 239-267.

-, 2008, The rainfall intensity-duration control of shallow landslides and debris flows: an update: Landslides, v. 5, no. 1, p. 3-17.

Hampton, M. A., Lee, H. J., and Locat, J., 1996, Submarine landslides: Reviews of geophysics, v. 34, no. 1, p. 33-59.

Houghton, B., and Cuthbertson, A., 1989, Sheet T14BD Kaimai; Geological Map of New Zealand 1: 50,000: Dept. Sci. Indus. Res., Wellington, New Zealand.

Hsu, K. J., 1975, Catastrophic debris streams (sturzstroms) generated by rockfalls: Geological Society of America Bulletin, v. 86, no. 1, p. 129-140.

Imbert, T., and Desprairies, A., 1987, Neoformation of halloysite on volcanic glass in a marine environment: Clay Minerals, v. 22, no. 2, p. 179-185.

Irfan, T., 1992, Mineralogical assessment of creep-type instability at two landslip sites: Geotechnical Engineering office.

-, 1998, Structurally controlled landslides in saprolitic soils in Hong Kong: Geotechnical \& Geological Engineering, v. 16, no. 3, p. 215-238.

Jeong, G., and Kim, S., 1996, Morphology of halloysite particles and aggregates in the weathering of anorthosite: Journal of the Mineralogical Society of Korea, v. 9, p. 64-70.

Jorat, M. E., Moon, V. G., Hepp, D. A., Kreiter, S., de Lange, W. P., Feldmann, S., and Mörz, T., 2017, Subseafloor investigation of sediments at Southern Tauranga Harbour, New Zealand, before capital dredging: Journal of Coastal Research, v. 33, no. 2, p. 227-242.

Joussein, E., Petit, S., Churchman, J., Theng, B., Righi, D., and Delvaux, B., 2005, Halloysite clay minerals-a review: Clay Minerals, v. 40, no. 4, p. 383-426.

Kirk, P., Campbell, S., Fletcher, C., and Merriman, R., 1997, The significance of primary volcanic fabrics and clay distribution in landslides in Hong Kong: Journal of the Geological Society, v. 154, no. 6, p. 1009-1019.

Kirkman, J., 1977, Possible structure of halloysite disks and cylinders observed in some New Zealand rhyolitic tephras: Clay Minerals, v. 12, p. 199.

Kluger, M. O., Kreiter, S., Moon, V., Orense, R. P., Mills, P., and Moerz, T., 2018, Undrained cyclic shear behaviour of weathered tephra Géotechnique. 
Kluger, M. O., Moon, V. G., Kreiter, S., Lowe, D. J., Churchman, G., Hepp, D. A., Seibel, D., Jorat, M. E., and Mörz, T., 2017, A new attraction-detachment model for explaining flow sliding in clay-rich tephras: Geology, v. 42, no. 2, p. 131-134.

Kvalstad, T. J., Andresen, L., Forsberg, C. F., Berg, K., Bryn, P., and Wangen, M., 2005, The Storegga slide: evaluation of triggering sources and slide mechanics: Marine and Petroleum Geology, v. 22, no. 1, p. 245-256.

- $\quad$ L'Heureux, J.-S., Eilertsen, R. S., Glimsdal, S., Issler, D., Solberg, I.-L., and Harbitz, C. B., 2012, The 1978 quick clay landslide at Rissa, mid Norway: subaqueous morphology and tsunami simulations, Submarine mass movements and their consequences, Springer, p. 507-516.

L'Heureux, J.-S., Locat, A., Leroueil, S., Demers, D., and Locat, J., 2014, Landslides in Sensitive Clays-From Geosciences to Risk Management, Landslides in Sensitive Clays, Springer, p. 112.

- Labuz, J. F., and Zang, A., 2012, Mohr-Coulomb failure criterion: Rock mechanics and rock engineering, v. 45, no. 6, p. 975-979.

Larsen, I. J., Montgomery, D. R., and Korup, O., 2010, Landslide erosion controlled by hillslope material: Nature Geoscience, v. 3, no. 4, p. 247.

Longva, O., Janbu, N., Blikra, L., and Bøe, R., 2003, The 1996 Finneidfjord slide; seafloor failure and slide dynamics, Submarine Mass movements and their consequences, Springer, p. 531538.

- $\quad$ Loughnan, F., and Roberts, F. I., 1981, The natural conversion of ordered kaolinite to halloysite (1 at Burning Mountain near Wingen'New South Wales: American Mineralogist, v. 66, p. $997-$ 1005.

Lowe, D. J., 2011, Tephrochronology and its application: a review: Quaternary Geochronology, v. 6, no. 2, p. 107-153.

Malamud, B. D., Turcotte, D. L., Guzzetti, F., and Reichenbach, P., 2004, Landslides, earthquakes, and erosion: Earth and Planetary Science Letters, v. 229, no. 1-2, p. 45-59.

Martelloni, G., Segoni, S., Fanti, R., and Catani, F., 2012, Rainfall thresholds for the forecasting of landslide occurrence at regional scale: Landslides, v. 9, no. 4, p. 485-495.

Moon, V., de Lange, W., Garae, C., Mörz, T., Jorat, M., and Kreiter, S., 2015a, Monitoring the landslide at Bramley Drive, Tauranga, NZ.

Moon, V. G., Lowe, D. J., Cunningham, M. J., Wyatt, J. B., de Lange, W. P., Churchman, G. J., Mörz, T., Kreiter, S., Kluger, M. O., and Jorat, M. E., Sensitive pyroclastic-derived halloysitic soils in northern New Zealand: Interplay of microstructure, minerals, and geomechanics, in Proceedings Volcanic Rocks and Soils2015b, Taylor and Francis, London, p. 3-21.

Napolitano, E., Fusco, F., Baum, R. L., Godt, J. W., and De Vita, P., 2016, Effect of antecedenthydrological conditions on rainfall triggering of debris flows in ash-fall pyroclastic mantled slopes of Campania (southern Italy): Landslides, v. 13, no. 5, p. 967-983.

Nicoletti, P. G., and Sorriso-Valvo, M., 1991, Geomorphic controls of the shape and mobility of rock avalanches: Geological Society of America Bulletin, v. 103, no. 10, p. 1365-1373.

Norsk Geoteknisk Forening, 1974, Retningslinjer for presentasjon av geotekniske undersökelser: Oslo, Norway, v. 16.

Parham, W. E., 1970, SP-10 Clay Mineralogy and Geology of Minnesota's Kaolin Clays.

- Parry, S., Campbell, S., and Churchman, G., Kaolin-Rich Zones In Hong Kong Saprolites Their Interpretation And Engineering Significance, in Proceedings ISRM International Symposium2000, International Society for Rock Mechanics.

-, 2001, The origin and shear strength of kaolin-rich zones in Hong Kong: Geotech. Engn, p. 893897.

Peruccacci, S., Brunetti, M. T., Luciani, S., Vennari, C., and Guzzetti, F., 2012, Lithological and seasonal control on rainfall thresholds for the possible initiation of landslides in central Italy: Geomorphology, v. 139, p. 79-90.

Pouclet, A., Cambray, H., Cadet, J.-P., Bourgois, J., and De Wever, P., 28. VOLCANIC ASH FROM LEG 112 OFF PERU1, in Proceedings Proceedings of the Ocean Drilling Program: Scientific results1990, The Program, p. 465.

Quantin, P., and Rambaud, D., 1987, Genesis of spherical halloysite from basaltic ash, at Ambrym (Vanuatu). 
- Quayle, A., 1984, The climate and weather of the Bay of Plenty region, Ministry of Transport, New Zealand Meteorological Service.

- $\quad$ Rahardjo, H., Lee, T., Leong, E. C., and Rezaur, R., 2005, Response of a residual soil slope to rainfall: Canadian Geotechnical Journal, v. 42, no. 2, p. 340-351.

Romero, R., Robert, M., Elsass, F., and Garcia, C., 1992, Abundance of halloysite neoformation in soils developed from crystalline rocks. Contribution of transmission electron microscopy: Clay Minerals, v. 27, no. 1, p. 35-46.

Rosi, A., Lagomarsino, D., Rossi, G., Segoni, S., Battistini, A., and Casagli, N., 2015, Updating EWS rainfall thresholds for the triggering of landslides: Natural Hazards, v. 78, no. 1, p. 297308.

- Rösner, A., 2016, Impact of seismicity on Nice's slope stability [M.Sc.: University of Bremen.

- Saigusa, M., Shoji, S., and Kato, T., 1978, Origin and nature of halloysite in Ando soils from Towada tephra, Japan: Geoderma, v. 20, no. 2, p. 115-129.

Scheidegger, A. E., 1973, On the prediction of the reach and velocity of catastrophic landslides: Rock Mechanics and Rock Engineering, v. 5, no. 4, p. 231-236.

Segoni, S., Piciullo, L., and Gariano, S. L., 2018a, A review of the recent literature on rainfall thresholds for landslide occurrence: Landslides, v. 15, no. 8, p. 1483-1501.

Segoni, S., Rosi, A., Lagomarsino, D., Fanti, R., and Casagli, N., 2018b, Brief communication: Using averaged soil moisture estimates to improve the performances of a regional-scale landslide early warning system: Natural Hazards and Earth System Sciences, v. 18, no. 3, p. 807-812.

- Shaller, P., Sykora, D., Doroudian, M., and Churchman, G. J., 2016, Rapid in situ conversion of late-stage volcanic materials to halloysite implicated in catastrophic dam failure, Hawaii: Clay Minerals, v. 51, no. 3, p. 499-515.

- $\quad$ Shepherd, M., Betts, H., McFadgen, B., and Sutton, D., 2000, Geomorphological evidence for a Pleistocene barrier at Matakana Island, Bay of Plenty, New Zealand: New Zealand Journal of Geology and Geophysics, v. 43, no. 4, p. 579-586.

Sidle, R. C., and Ochiai, H., 2006, Landslides: processes, prediction, and land use, Washington, DC, American Geophysical Union, Water resources monograph series.

Sieffermann, G., and Millot, G., Equatorial and tropical weathering of recent basalts from Cameroon: allophanes, halloysite, metahalloysite, kaolinite and gibbsite, in Proceedings Proceedings of the International Clay Conference, Tokyo1969, Volume 1, Israel University Press, Jerusalem, p. 417-430.

Singer, A., Zarei, M., Lange, F., and Stahr, K., 2004, Halloysite characteristics and formation in the northern Golan Heights: Geoderma, v. 123, no. 3, p. 279-295.

- Skempton, A., and Northey, R., 1952, The sensitivity of clays: Geotechnique, v. 3, no. 1, p. 30-53.

- Smalley, I., Ross, C. W., and Whitton, J., 1980, Clays from New Zealand support the inactive particle theory of soil sensitivity: Nature, v. 288, p. 576-577.

- $\quad$ Tanaka, K., 1992, Slope hazards and clay minerals: Nendo Kagaku, v. 32, no. 1, p. 16-22.

- Taskey, R. D., 1977, Relationships of clay mineralogy to landscape stability in Western Oregon.

- Tiranti, D., and Rabuffetti, D., 2010, Estimation of rainfall thresholds triggering shallow landslides for an operational warning system implementation: Landslides, v. 7, no. 4, p. 471481.

- Torrance, J. K., 1983, Towards a general model of quick clay development: Sedimentology, v. 30, no. 4 , p. $547-555$.

-, 1992, Discussion on sensitivity to remoulding ofsome volcanic ash soils in New Zealand, by D. Jacquet: Engineering Geology, v. 32, no. 1, p. 101-105.

- $\quad$ Varnes, D. J., 1978, Slope movement types and processes: Special report, v. 176, p. 11-33.

- Wada, K., and Kakuto, Y., 1985, Embryonic halloysites in Ecuadorian soils derived from volcanic ash: Soil Science Society of America Journal, v. 49, no. 5, p. 1309-1318.

- $\quad$ Wang, G., Suemine, A., Zhang, F., Hata, Y., Fukuoka, H., and Kamai, T., 2014, Some fluidized landslides triggered by the 2011 Tohoku Earthquake (M w 9.0), Japan: Geomorphology, v. 208, p. 11-21.

- Wei, L.-W., Huang, C.-M., Chen, H., Lee, C.-T., Chi, C.-C., and Chiu, C.-L., 2018, Adopting the I 3-R 24 rainfall index and landslide susceptibility for the establishment of an early warning 
model for rainfall-induced shallow landslides: Natural Hazards \& Earth System Sciences, v.

$1788 \quad 18$, no. 6.

2789 - Wen, B., and Aydin, A., 2003, Microstructural study of a natural slip zone: quantification and deformation history: Engineering Geology, v. 68, no. 3, p. 289-317.

- Yamao, M., Sidle, R., Gomi, T., and Imaizumi, F., 2016, Characteristics of landslides in unwelded pyroclastic flow deposits, southern Kyushu, Japan: Natural Hazards and Earth System Sciences, v. 16, no. 2, p. 617-627.

- Zaruba, Q., and Mencl, V., 2014, Landslides and their control, Elsevier. 


\section{FIGURE CAPTIONS}

Fig. 1. Study area. A: Distribution of coastal landslides along the northwest coast of Omokoroa. The topographic map is overlain by landslide main scarps, landslide dimensions, and bathymetry data from the near shore area. B: Location of Omokoroa Peninsula within the estuarine lagoon of Tauranga Harbour, northern New Zealand. C-E: Photographs of coastal landslides at Omokoroa. The locations are indicated in Fig. 1A. Maps in Fig. 1 were created by using a 250-m-resolution national bathymetry grid, provided by NIWA, licensed under NODL By-NN-NC-Sa 1.0, an 8-m-resolution regional digital elevation model, and a 1-m-resolution local LIDAR digital elevation model, both provided by LINZ, licensed under CC BY 4.0.

Fig. 2. Geology of the 1979 Bramley Drive landslide. A: Stratigraphy of the succession of lignite, ignimbrite, and tephra-fall deposits, and intervening paleosols (P). B: Relative concentrations of different halloysite clay morphologies with depth (after Kluger et al., 2017). C: Cross-section of the 1979 Bramley Drive landslide showing the locations of the confined and unconfined aquifers, respectively, with locations of upper $(\mathrm{U})$, middle $(\mathrm{M})$, and lower (L) piezometers. Upper and lower tidal ranges are from de Lange (1993). D: Scanning electron microscope images of mushroom cap-shaped spheroidal halloysite, which is abundant in the highly sensitive layer within the Pahoia Tephras. The images are modified with permission from Kluger et al. (2017), copyright 2017 The Geological Society of America.

Fig. 3 Pore water pressure (PWP) and rainfall characteristics. A-B: PWP and hourly rainfall time series from January 2014 to June 2018. Green circles indicate large rainfall events (defined in the text) having been taken from rain gauges at the Bramley Drive landslide (dark green) or at Goodall Road, Whakamarama (light green). C-D: Rainfall correlations between rain gauges at Bramley Drive landslide and Goodall Road, Whakamarama. E: Hourly rainfall, PWP, and number of recent landslides during the 2017 cyclone season.

Fig. 4. Landslide dimensions. $r^{2}$ is the coefficient of determination.

Fig. 5. Sedimentary architecture of the subtidal area, northwest Omokoroa. A: Along-shore and B: cross-shore seismic profiles and interpretation of seismic units.

Fig. 6. Effect of rainfall events on effective stress decrease. Changes in water table and effective stress in the soil slope of the Bramley Drive landslide with A: rainfall intensity and B: duration of rainfall events. The length of arrows indicates the change in water table and effective stress, respectively. The colors of the arrows represent the increase in water table as defined in the color scale. 
833 Fig. 7. Rainfall thresholds Rainfall intensity-duration relationships of small and large rainfall events

1

2 plotted on A: logarithmic and B: linear scales. The black dashed lines represent the two rainfall thresholds proposed by Sidle and Ochiai (2006) and Wei et al. (2018). The black line represents the effective stress threshold, which is calibrated for the lower bound of large rainfall events at the $5 \%$ confidence interval. The colors of symbols and of the stacked bar chart are defined in the legend of Fig. 7B.

\section{TABLES}

Table 1. Coastal landslides at Omokoroa Peninsula, Tauranga Harbour, New Zealand.

\begin{tabular}{|c|c|c|c|c|c|c|c|c|c|c|c|c|c|c|}
\hline \multirow{2}{*}{$\begin{array}{l}\text { Land } \\
\text {-slide } \\
\text { No. }\end{array}$} & \multirow[t]{2}{*}{ Location } & \multirow{2}{*}{$\begin{array}{l}\text { Material } \\
\text { composition }\end{array}$} & \multirow[t]{2}{*}{ Type } & \multicolumn{10}{|c|}{ Landslide dimension } & \multirow[t]{2}{*}{ Timing } \\
\hline & & & & $D_{s}$ & $W_{s}$ & $L_{s}$ & $H$ & $L$ & $A_{L}$ & $V_{T}$ & $V_{r}$ & $H / L$ & $\beta$ & \\
\hline & & & & $\mathrm{m}$ & $\mathrm{m}$ & $\mathrm{m}$ & \begin{tabular}{|l|l}
$\mathrm{m}$ \\
\end{tabular} & $\mathrm{m}$ & $\mathrm{m}^{2}$ & $\mathrm{~m}^{3}$ & $\mathrm{~m}^{3}$ & & $\circ$ & \\
\hline L-1 & $\begin{array}{l}\text { Waterview } \\
\text { Ter }\end{array}$ & TPI, PT*, & $\mathrm{D}^{\mathrm{S}}$ & 7 & 25 & 25 & 20 & 30 & 625 & & 2,291 & 0.67 & 34 & A \\
\hline L-2 & \multirow{4}{*}{$\begin{array}{l}\text { Hamurana } \\
\text { Rd - } \\
\text { Kaharoa Av }\end{array}$} & TPI*, PT & $\mathrm{S}$ & & 185 & 6 & 5 & 8 & 1,185 & 1,811 & & 0.67 & 34 & A \\
\hline L-3-1 & & TPI & $\mathrm{S}$ & & 30 & 32 & 20 & 50 & 960 & 1,370 & & 0.40 & 22 & A \\
\hline L-3-2 & & TPI*, PT & $\mathrm{D}$ & 5.5 & 15 & 14 & 10 & 20 & 212 & & 611 & 0.50 & 27 & $\mathrm{~A}$ \\
\hline L-3-3 & & PT & $\mathrm{S}$ & & 5 & 10 & 7 & 10 & 49 & 26 & & 0.70 & 35 & $\mathrm{~A}$ \\
\hline L-4 & Kaharoa Av & N/A & $\mathrm{D}^{\mathrm{S}}$ & 4 & 15 & 16 & 10 & 12 & 234 & & 491 & 0.83 & 40 & A \\
\hline L-5 & \multirow[t]{2}{*}{ Kowai Grv } & TPI, PT*, & $\mathrm{D}$ & 9 & 30 & 32 & 20 & 38 & 960 & & 4,526 & 0.53 & 28 & $\mathrm{~A}$ \\
\hline L-6 & & TPI & $\mathrm{S}$ & & 29 & 29 & 20 & 21 & 841 & 1,148 & & 0.95 & 44 & $\mathrm{~A}$ \\
\hline L-7 & \multirow{3}{*}{$\begin{array}{l}\text { McDonnell } \\
\text { St }\end{array}$} & N/A & $\mathrm{S}$ & & 20 & 25 & 15 & 25 & 500 & 574 & & 0.60 & 31 & A \\
\hline L-8 & & TPI & $\mathrm{S}$ & & 48 & 9 & 8 & 5 & 410 & 441 & & 1.60 & 58 & $\mathrm{~A}$ \\
\hline L-9 & & TPI, PT*, & $\mathrm{D}^{\mathrm{S}}$ & 14 & 25 & 58 & 30 & 115 & 1,458 & & 10,686 & 0.26 & 15 & $\mathrm{~A}$ \\
\hline L-10 & \multirow{3}{*}{ Bramley Dr } & PT, HA & $\mathrm{S}$ & & 64 & 36 & 30 & 30 & 2,308 & 4,403 & & 1.00 & 45 & A \\
\hline L-11 & & PT, HA & $\mathrm{D}$ & 27 & 62 & 68 & 32 & 210 & 4,216 & & 59,602 & 0.15 & 9 & $1979 \dagger$ \\
\hline L-12 & & PT, HA & $\mathrm{S}$ & & 10 & 17 & 15 & 15 & 170 & 136 & & 1.00 & 45 & $A \neq, B$ \\
\hline L-13 & \multirow{3}{*}{$\begin{array}{l}\text { Ruamoana } \\
\text { Pl }\end{array}$} & PT, HA & $\mathrm{S}$ & & 14 & 25 & 21 & 25 & 343 & 348 & & 0.85 & 41 & A \\
\hline L-14 & & PT & $\mathrm{D}$ & 6 & 19 & 15 & 9 & 30 & 278 & & 872 & 0.30 & 17 & B \\
\hline L-15 & & PT & $\mathrm{D}$ & 7 & 15 & 15 & 9 & 30 & 225 & & 825 & 0.30 & 17 & B \\
\hline L-16 & \multirow[t]{3}{*}{ Myrtle Dr } & TPI*, PT & $\mathrm{D}$ & 4 & 14 & 17 & 8 & 25 & 235 & & 491 & 0.32 & 18 & $\mathrm{~A} \ddagger, \mathrm{B}$ \\
\hline L-17 & & TPI & $\mathrm{S}$ & & 15 & 9 & 8 & 10 & 142 & 107 & & 0.80 & 39 & A \\
\hline L-18 & & TPI & $\mathrm{S}$ & & 30 & 18 & 15 & 20 & 541 & 637 & & 0.75 & 37 & B \\
\hline L-19 & \multirow{7}{*}{$\begin{array}{l}\text { Crapp His- } \\
\text { toric Re- } \\
\text { serve }\end{array}$} & TPI, PT, HA & $\mathrm{S}$ & & 35 & 14 & 14 & 10 & 484 & 550 & & 1.35 & 53 & A \\
\hline L-20 & & TPI, PT, HA & $\mathrm{S}$ & & 7 & 20 & 20 & 10 & 142 & 107 & & 2.00 & 63 & $\mathrm{~A}$ \\
\hline L-21 & & TPI, PT, HA & $\mathrm{S}$ & & 25 & 12 & 12 & 10 & 309 & 303 & & 1.20 & 50 & $\mathrm{~A}$ \\
\hline $\mathrm{L}-22$ & & TPI, PT, HA & $\mathrm{S}$ & & 15 & 11 & 10 & 20 & 168 & 134 & & 0.50 & 27 & $\mathrm{~A}$ \\
\hline L-23 & & TPI, PT, HA & $\mathrm{S}$ & & 8 & 13 & 13 & 7 & 107 & 73 & & 1.86 & 62 & $\mathrm{~A}$ \\
\hline L-24 & & TPI, PT, HA & $\mathrm{S}$ & & 11 & 14 & 14 & 6 & 152 & 118 & & 2.25 & 66 & $\mathrm{~A}$ \\
\hline $\mathrm{L}-25$ & & TPI, PT, HA & $\mathrm{S}$ & & 21 & 12 & 10 & 10 & 257 & 236 & & 0.95 & 44 & $\mathrm{~A}$ \\
\hline L-26 & $\begin{array}{l}\text { Harbour } \\
\text { View Rd }\end{array}$ & TPI & $\mathrm{D}^{\mathrm{S}}$ & 6 & 20 & 28 & 19 & 50 & 552 & & 1,733 & 0.38 & 21 & A \\
\hline
\end{tabular}

*Base of slide surface

$\dagger 1979$ Bramley Drive landslide dimensions from Gulliver and Houghton (1980)

\$Main failure event

Ter-Terrace; Rd-Road; Av-Avenue; Grv-Grove; St-Street; Dr-Drive; Pl-Place

TPI-Te Puna Ignimbrite; PT-Pahoia Tephras; HA-Hamilton Ashes; N/A-Not available

D-deep-seated; S-shallow; $\mathrm{D}^{\mathrm{S}}$-complex earth slide with deep-seated being the dominant mode of failure and shallow failure associated to the main event

A-Cyclone Debbie (April 5 $\left.5^{\text {th }}, 2017\right)$; B-Cyclone Cook (April 13 $3^{\text {th }}, 2017$ ) 
Table 2. Definitions of predictive capability variables.

\begin{tabular}{|l|l|l|}
\hline Variable & Name & Description \\
\hline$T P$ & True positives & $\begin{array}{l}\text { Threshold exceeded; landslide(s)/effective stress decrease } \\
\text { occurred }\end{array}$ \\
\hline$T N$ & True negatives & $\begin{array}{l}\text { Threshold not exceeded; landslide(s)/effective stress de- } \\
\text { crease did not occur }\end{array}$ \\
\hline$F P$ & False positives & $\begin{array}{l}\text { Threshold exceeded; landslide(s)/effective stress decrease } \\
\text { did not occur }\end{array}$ \\
\hline$F N$ & False negatives & $\begin{array}{l}\text { Threshold not exceeded; landslide(s)/effective stress de- } \\
\text { crease occurred }\end{array}$ \\
\hline$S e=\frac{T P}{T P+F N}$ & Sensitivity & $\begin{array}{l}\text { Ability to properly classify rainfalls that caused land- } \\
\text { slide(s)/effective stress decrease }\end{array}$ \\
\hline$S p=\frac{T N}{T N+F P}$ & Specificity & $\begin{array}{l}\text { Ability to properly classify rainfalls that did not cause land- } \\
\text { slide(s)/effective stress decrease }\end{array}$ \\
\hline$P P P=\frac{T P}{F P+T P}$ & Positive prediction power & $\begin{array}{l}\text { Probability of correctly classifying a rainfall that caused } \\
\text { landslide(s)/effective stress decrease }\end{array}$ \\
\hline$N P P=\frac{T N}{T N+F N}$ & Negative prediction power & $\begin{array}{l}\text { Probability of correctly classifying a rainfall that did not } \\
\text { cause landslide(s)/effective stress decrease }\end{array}$ \\
\hline
\end{tabular}

852 Table 3. Variables* of predictive capability for the rainfall thresholds considered in this study.

\begin{tabular}{|l|l|l|l|l|l|l|l|l|l|}
\hline Threshold & Aim & $\boldsymbol{T P}$ & $\boldsymbol{T N}$ & $\boldsymbol{F P}$ & $\boldsymbol{F N}$ & $\boldsymbol{S e}$ & $\boldsymbol{S p}$ & $\boldsymbol{P P P}$ & $\boldsymbol{N P P}$ \\
\hline Sidle and Ochiai (2006) & Landslide occurrence & 2 & 798 & 34 & 0 & 1.000 & 0.959 & 0.056 & 1.000 \\
\hline Effective stress threshold & $\begin{array}{l}\text { Beginning of effective } \\
\text { stress decrease }\end{array}$ & 40 & 739 & 36 & 1 & 0.976 & 0.954 & 0.526 & 0.999 \\
\hline
\end{tabular}

$853 *$ Defined in Table 2. 

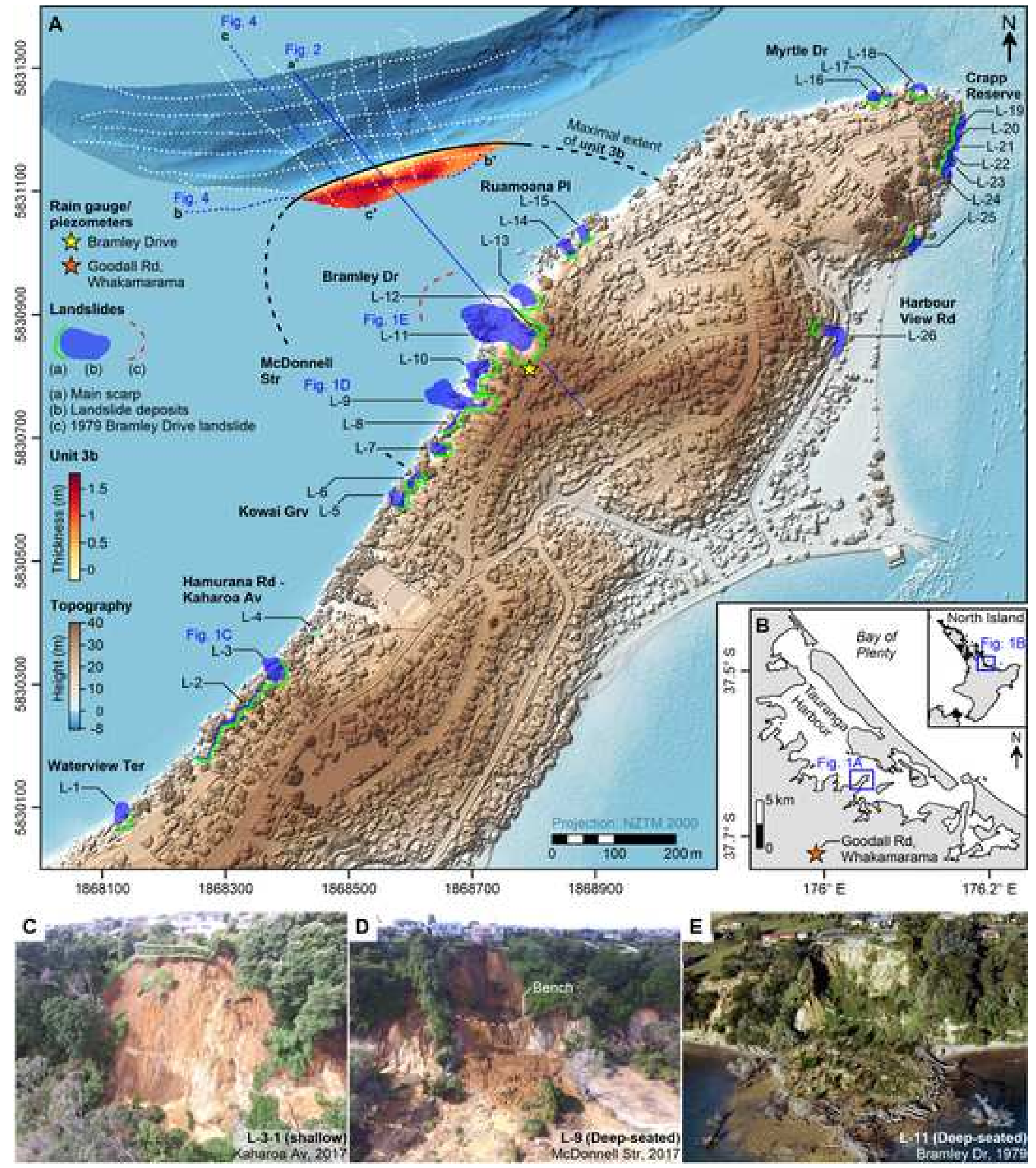
AFigure 2 ate Quaternary

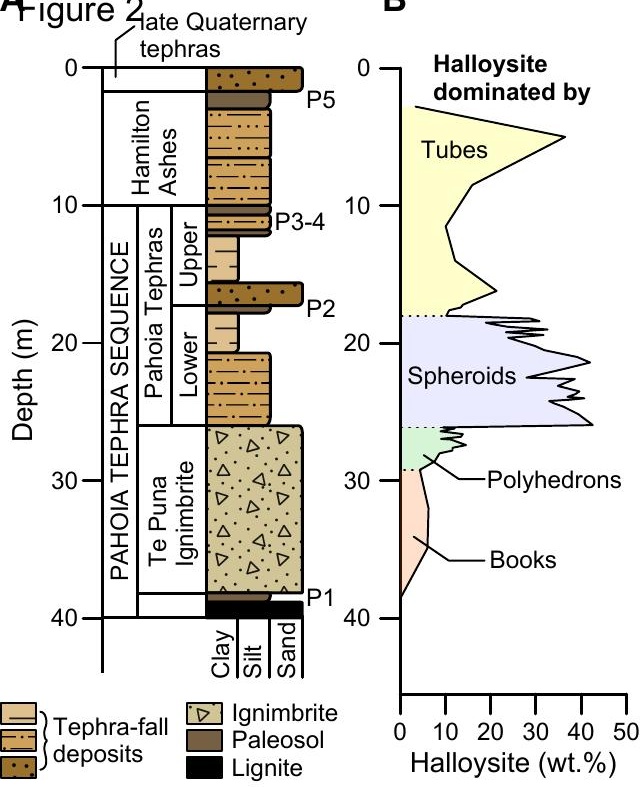

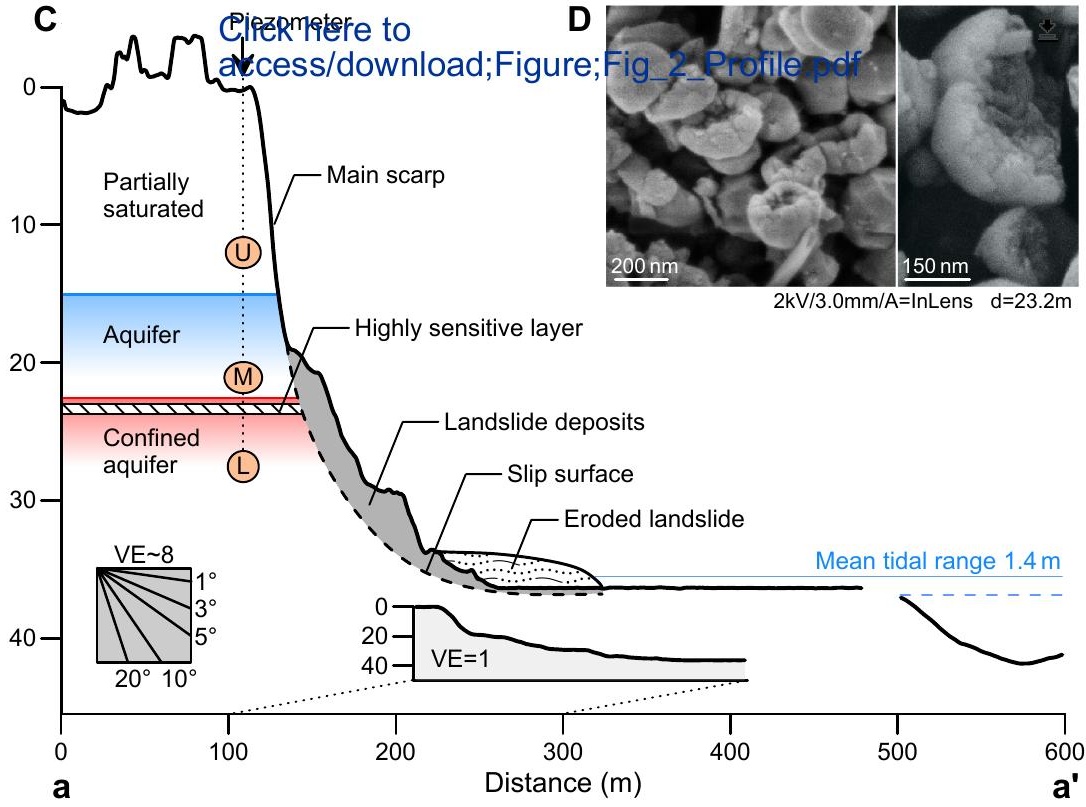

D

$2 \mathrm{kV} / 3.0 \mathrm{~mm} / \mathrm{A}=\operatorname{InLens} \quad \mathrm{d}=23.2 \mathrm{~m}$

Mean tidal range $1.4 \mathrm{~m}$

$a^{\prime}$
Cipermitere to cess/download;Figure

$$
5
$$


Áigure 3

管响

Depth Stratjgraphyere to

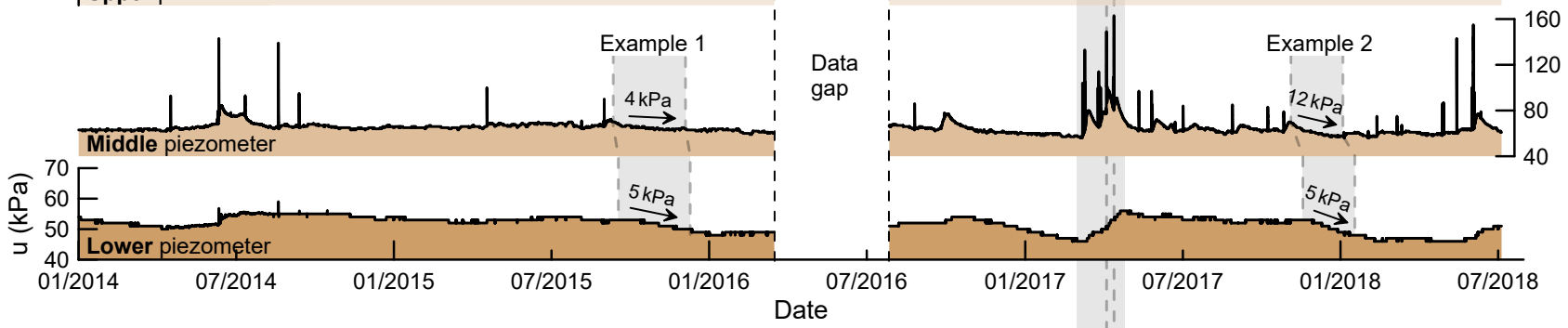

See blow-up in $\mathbf{E}$ Cyclone Debbie \& Cook Bramley Dr

Rainfall Large rainfall events

Goodall Rd,

$21 \mathrm{~m}$ Lower Pahoia Teph

$27.5 \mathrm{~m}$ Te Puna Ignimbrite

B

Whakamarama

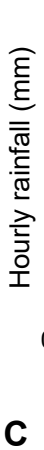

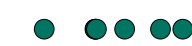

0

$07 / 2014$

$01 / 2015$

07/2015

Date

$07 / 2016$

$01 / 2017$
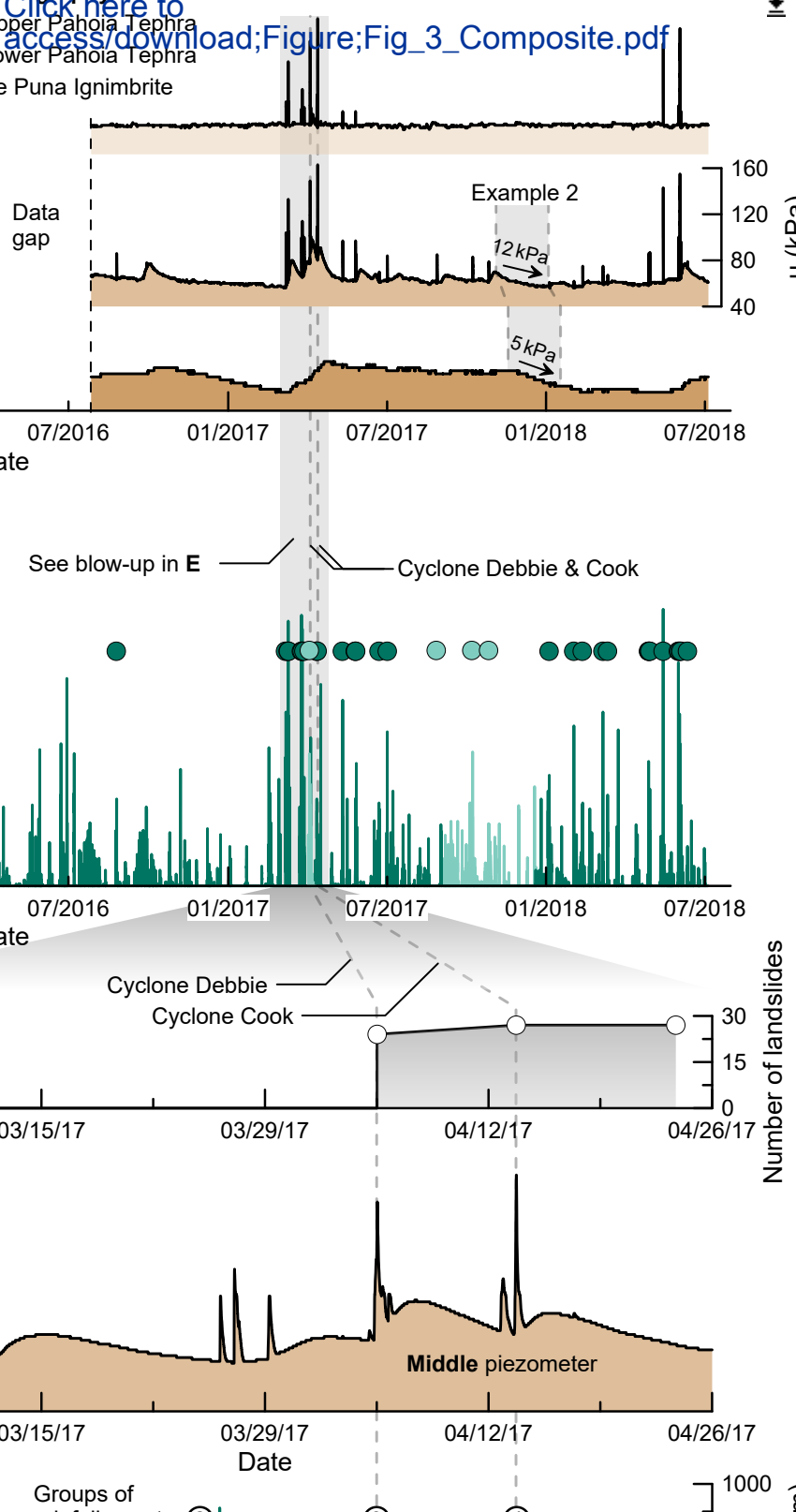

E

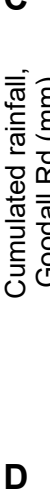

$160[y=1.02 x$
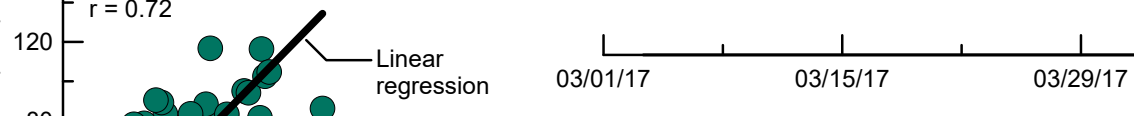

Cyclone Debbie -

Cyclone Cook

$07 / 2017$

$01 / 2018$

07/2018

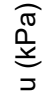

D.
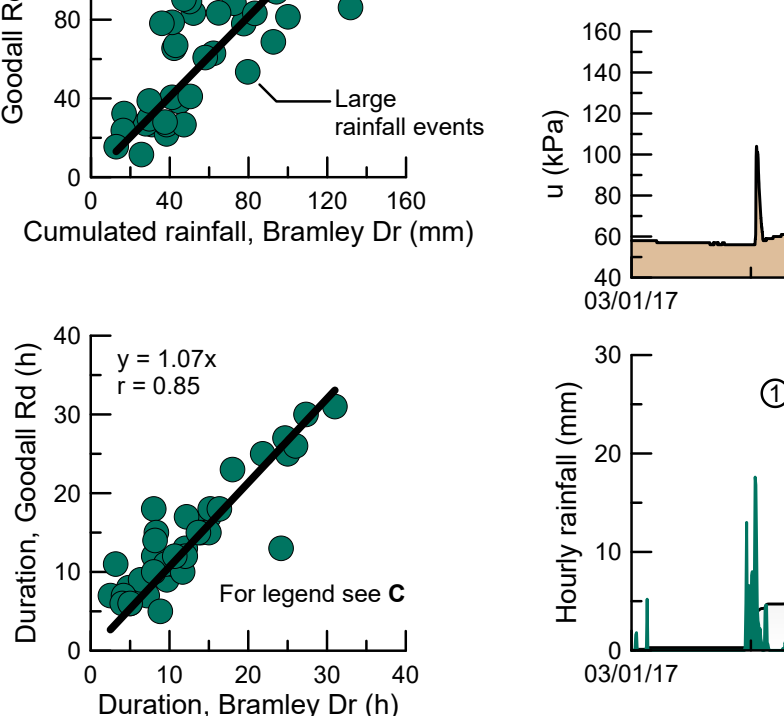

Cumulated rainfall, Bramley Dr (mm)
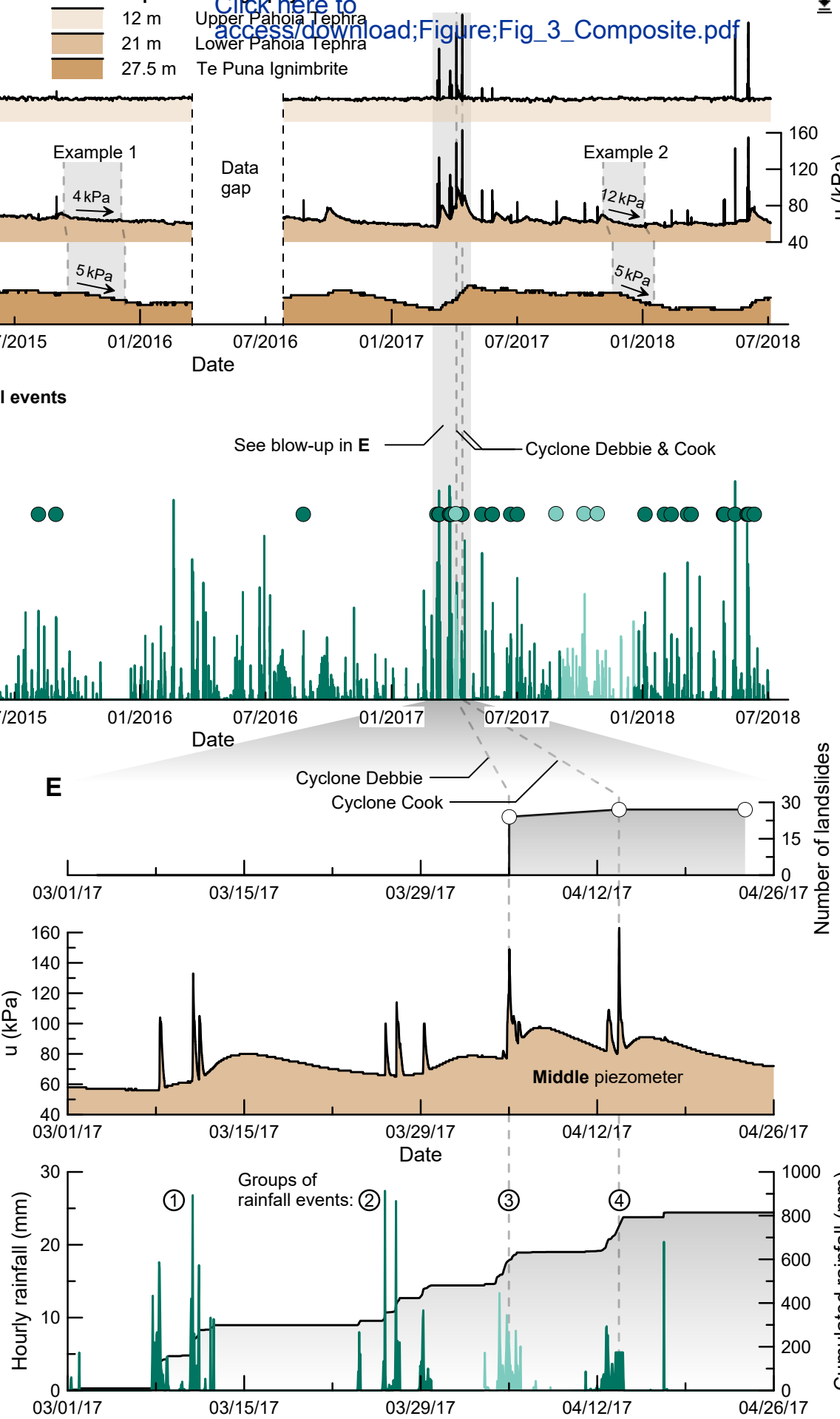

Groups of

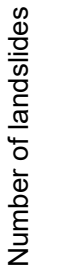


Figüre 4

Teiscktudyre to

Halloysitic soil

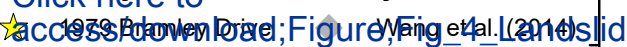
Pre-historic landslide Kirk et al. (1997)

Deep-seated

Shallow

(b)

Halloysitic soil

10

$10^{\circ}$

(c) $\beta=9.49 \mathrm{~V}^{-0.09}$

$r^{2}=0.50$

(d) $\beta=23.59 \mathrm{~V}^{-0.19}$

$r^{2}=0.50$

Subaerial landslides

$\nabla$ Edgers \& Karlsrud (1982)

Scheidegger (1973)

Hsü (1975)

Nicoletti \&

Sorriso-Valvo (1991)

$10^{-1}$

$10^{1}$
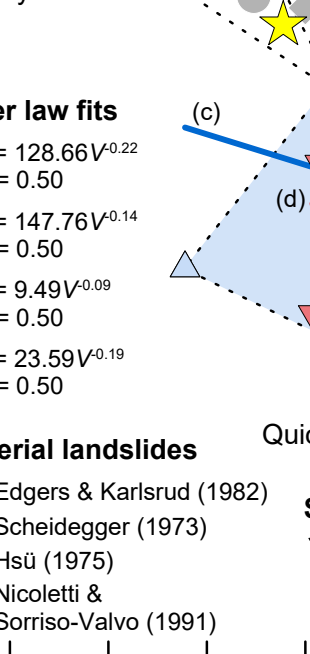

Irfan (1992)

Chigira et al. (2013)-

\section{Submarine landslides}

$\nabla$ L'Heureux et al. (2012)

$\triangle$ Hampton et al. (1996)

$\triangle$ Edgers \& Karlsrud (1982)

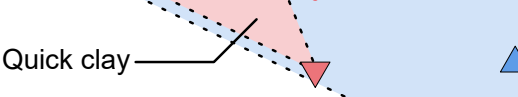

Subaerial
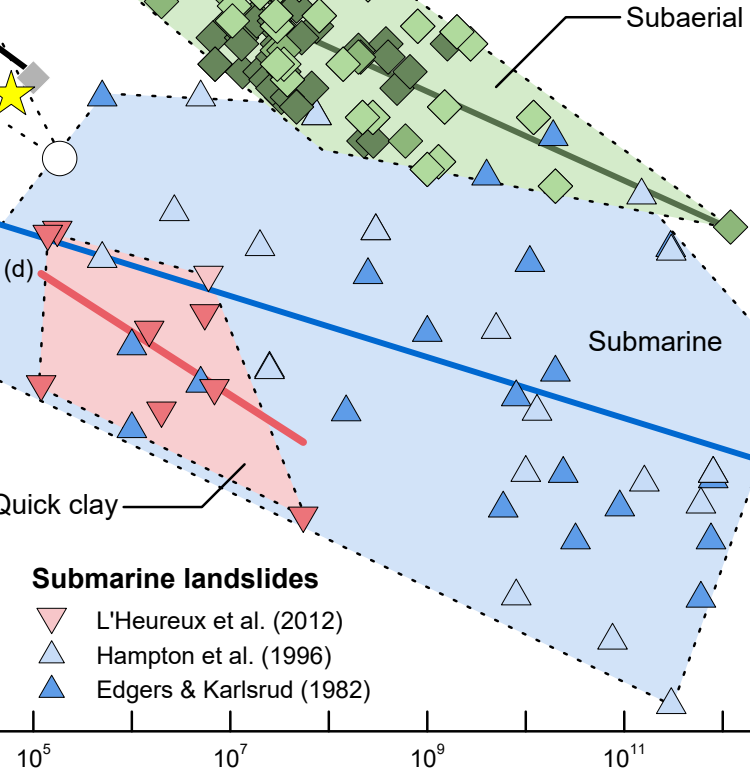

Volume $\left(\mathrm{m}^{3}\right)$ 


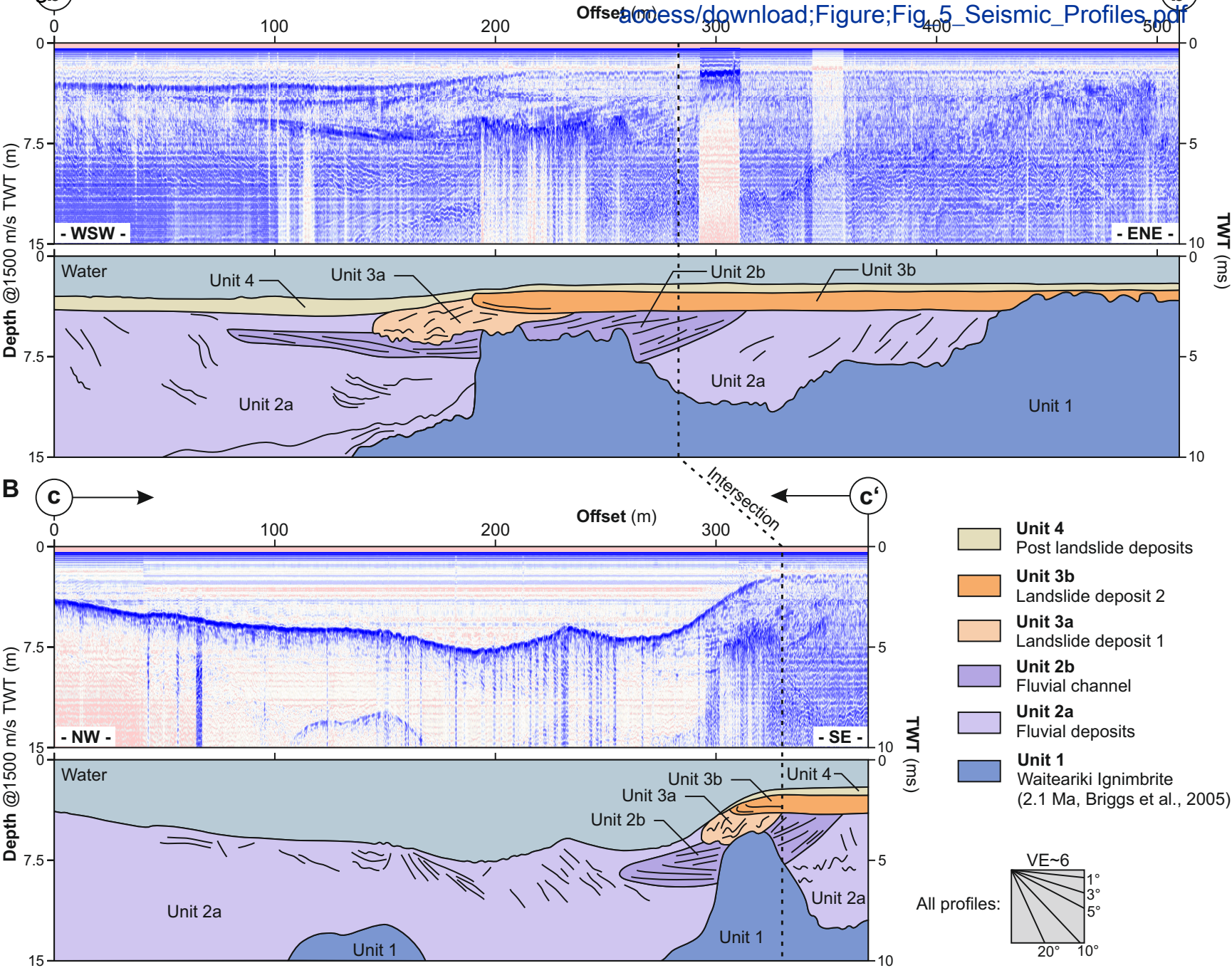

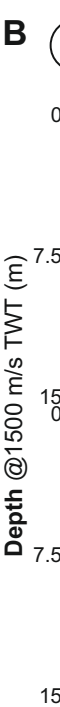
Unit 1 
Afigure $67^{9} \quad \begin{aligned} & \text { Cyclone Cook } \\ & \text { Three landslides }\end{aligned}$

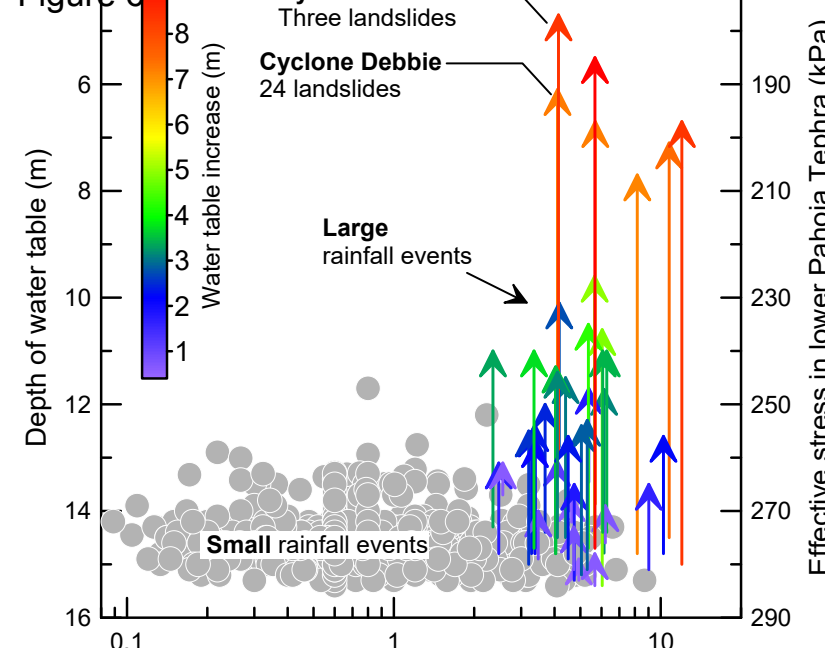

Rainfall intensity $(\mathrm{mm} / \mathrm{h})$

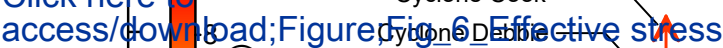

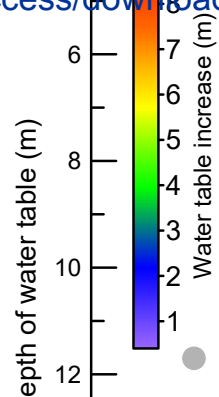

June 2018

rainfall event

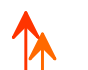

,

$\uparrow$

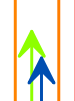

个

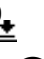

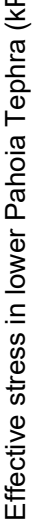

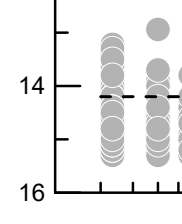

$\sigma_{\mathrm{b}}^{\prime}$ $\uparrow$

N小似 -250

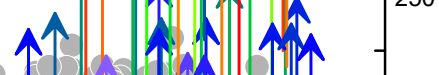

$-270$

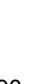

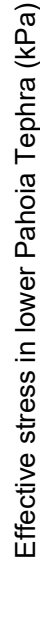

Duration (h) 
$\begin{array}{lll}\text { AFigur耳 } 7 & 27 \text { landslides during }\end{array}$

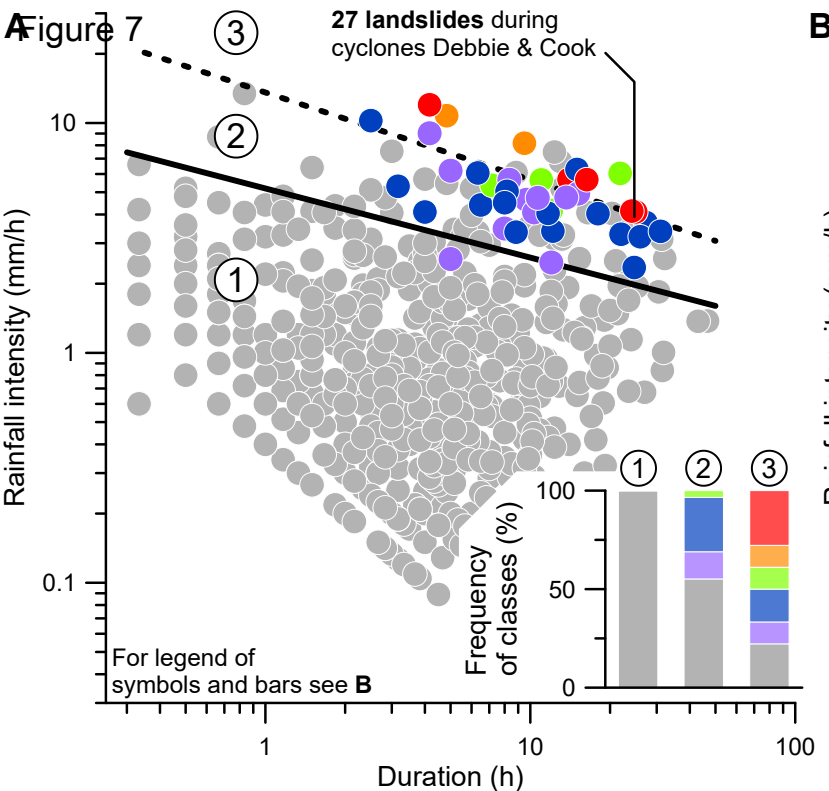

Class $\boldsymbol{\Delta} \boldsymbol{\sigma}_{\mathrm{N}}^{\prime}$

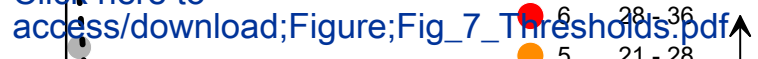

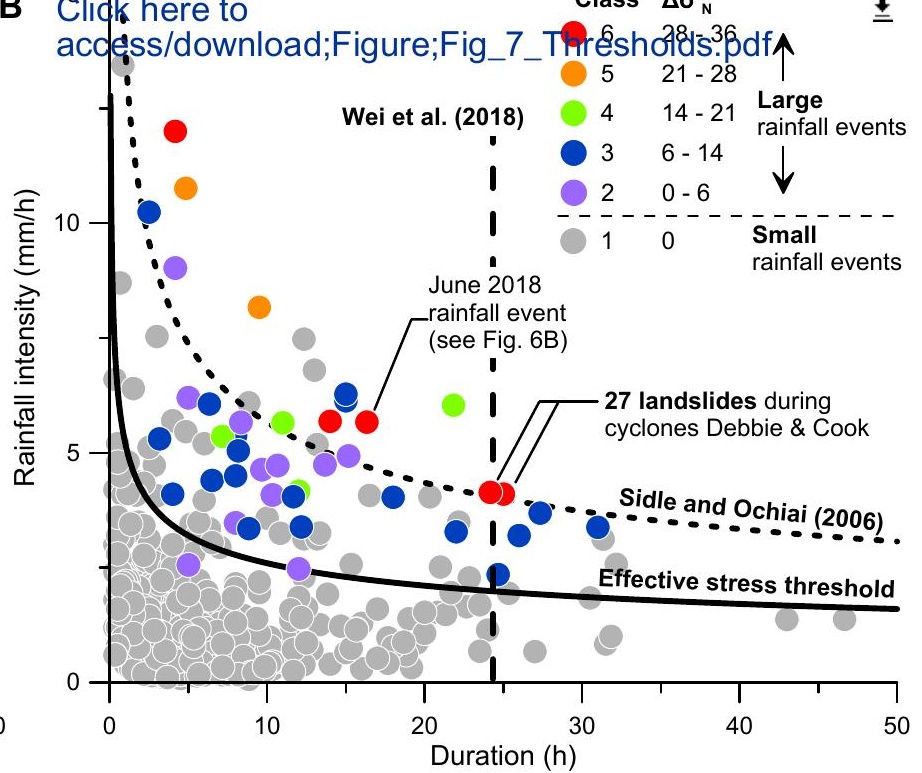

$\underline{\underline{ \pm}}$
B Elidk here to 